\title{
Activity of Isoxaflutole plus Metribuzin Tankmixes in Isoxaflutole-Resistant Soybean
}

\author{
Andrea Smith ${ }^{1}$, Nader Soltani ${ }^{1}$, David C. Hooker ${ }^{1}$, Darren E. Robinson' ${ }^{1}$, Allan C. Kaastra ${ }^{2}$, \\ Peter H. Sikkema ${ }^{1}$
}

${ }^{1}$ University of Guelph Ridgetown Campus, Ridgetown, ON, Canada

${ }^{2}$ Bayer Inc., Guelph, ON, Canada

Email: *soltanin@uoguelph.ca

How to cite this paper: Smith, A., Soltani, N., Hooker, D.C., Robinson, D.E., Kaastra, A.C. and Sikkema, P.H. (2019) Activity of Isoxaflutole plus Metribuzin Tankmixes in Isoxaflutole-Resistant Soybean. American Journal of Plant Sciences, 10, 1350-1373. https://doi.org/10.4236/ajps.2019.108097

Received: July 12, 2019

Accepted: August 23, 2019

Published: August 26, 2019

Copyright $\odot 2019$ by author(s) and Scientific Research Publishing Inc. This work is licensed under the Creative Commons Attribution International License (CC BY 4.0).

http://creativecommons.org/licenses/by/4.0/

\begin{abstract}
Isoxaflutole-resistant soybean is currently in development for commercialization in North America. Proposals to use isoxaflutole + metribuzin as the main herbicide tank-mixture raise concerns as there is limited grass control with these herbicides. Strategies are needed to improve grass control with isoxaflutole + metribuzin. Nine experiments were conducted over a two-year period $(2017,2018)$ to determine the efficacy of isoxaflutole + metribuzin $(52.5$ $+210 \mathrm{~g} \mathrm{a} \cdot \mathrm{i} \cdot \mathrm{ha}^{-1}$ ) applied alone and co-applied with pendimethalin, dimethenamid-P, pethoxamid, pyroxasulfone or S-metolachlor applied preemergence (PRE). Comparisons were made with isoxaflutole + metribuzin at a low rate $\left(52.5+210 \mathrm{~g} \mathrm{a} \cdot \mathrm{i} \cdot \mathrm{ha}^{-1}\right)$, medium rate $\left(79+315 \mathrm{~g} \mathrm{a} \cdot \mathrm{i} \cdot \mathrm{ha}^{-1}\right)$ and a high rate $(105$ $\left.+420 \mathrm{~g} \mathrm{a} \cdot \mathrm{i} \cdot \mathrm{ha}^{-1}\right)$. Eight weed species were evaluated including common lambsquarters, green and redroot pigweed, common ragweed, velvetleaf, green and giant foxtail, yellow foxtail, barnyardgrass and witchgrass. All herbicides were affected by amount of rainfall following application; less rainfall resulted in reduced weed control. The addition of pendimethalin, dimethenamid-P, pethoxamid, pyroxasulfone or S-metolachlor to the low rate ofisoxaflutole + metribuzin provided equivalent control of all weed species evaluated compared toisoxaflutole + metribuzin at the low, medium, or high rate.
\end{abstract}

\section{Keywords}

Glyphosate Resistance, HPPD Transgenic Soybean Cultivars, Preemergence Herbicides, Rainfall, Soybean Yield, Weed Management

\section{Introduction}

New hydroxyphenylpyruvate dioxygenase (HPPD) transgenic soybean cultivars 
are in development with resistance to a suite of herbicides including isoxaflutole and glyphosate; isoxaflutole, glyphosate and glufosinate; and isoxaflutole, mesotrione and glufosinate. Once commercialized, one weed management program will be the application of isoxaflutole + metribuzin applied preplant (PP) or preemergence (PRE) for residual control of annual grass and broadleaf weeds. These two herbicides, when used together, have complementary activity for the control of glyphosate-resistant (GR) Canada fleabane (Conyza canadensis L. Cronq.) [1]. However, this mixture does not provide full-season control of some annual grasses such as green foxtail (Setaria viridis L. P. Beauv.) and barnyardgrass (Echinochloa crus-galli L. P. Beauv.) [2] [3].

Isoxaflutole is an HPPD-inhibiting herbicide; this enzyme catalyzes the production of tocopherols and plastoquinone; a cofactor essential for carotenoid biosynthesis and an electron transporter in the electron transport chain [4]. Previously, isoxaflutole was only used in corn and sugarcane production. Metribuzin is a photosystem II (PSII)-inhibiting herbicide that displaces plastoquinone on the D1 protein of PSII causing a buildup of electrons in the electron transport chain [5]. Metribuzin primarily provides control of annual broadleaf weeds, although it does have some activitiy on annual grass weeds [6]. Therefore, one concern with the combined use of isoxaflutole and metribuzin in HPPD-resistant soybean is annual grass weed escapes.

Grass competition with soybean can cause a yield reduction; the amount of yield loss is influenced by weed species, density, relative time of weed and crop emergence, weather patterns, soil nutrient status and time of removal. Populations of Johnsongrass (Sorghum halepense L. Pers.) of 16 plants per $10 \mathrm{~m}$ of soybean row caused a $48 \%$ soybean yield loss; increases in weed density caused $88 \%$ yield loss [6]. Giant foxtail (Setaria faberi Herrm.) in competition with soybean at 177 plants. $\mathrm{m}^{-1}$ of row reduced soybean yield by $28 \%$ if they emerged early in the season; however, later emerging individuals caused little to no yield loss [7]. Quackgrass (Elymus repens L. Gould) caused an 11\% soybean yield reduction when allowed to compete with soybean for 6 weeks; an additional 2 weeks of competition caused an additional $12 \%$ yield loss [8].

Herbicides applied preemergence (PRE) with grass activity mitigates yield limiting soybean stress from grass weed competition early in the season. Soil applied grass herbicide families for soybean include dinitroaniline, chloroacetamide, chloroacetanilide and isoxazoline. Herbicides within these families control annual grasses and small-seeded broadleaf weeds; generally, they control barnyardgrass, crabgrass species (Digitaria sp.), Panicum species, foxtail species (Setaria spp.), Amaranthus species and common lambsquarters (Chenopodium album L.) although the weed spectrum controlled is active ingredient specific [6] [9] [10]. Herbicidal activity is dependent on rainfall within 7 days of application to ensure that the herbicide is dissolved in soil water solution so it can be absorbed by emerging weed seedlings [10]. Residual activity of dinitroaniline, chloroacetamide, chloroacetanilide and isoxazoline herbicides vary depending on soil moisture and individual soil-herbicide interactions. Pyroxasulfone + di- 
methenamid-P $\left(200+1138 \mathrm{~g}\right.$ a.i $\cdot$ ha $\left.^{-1}\right)$ and metolachlor $\left(1800 \mathrm{~g} \mathrm{a} \cdot \mathbf{i} \cdot \mathrm{ha}^{-1}\right)$ can provide 63 and 93 days residual control of barnyardgrass, respectively [11]. Other results show pethoxamid and pendimethalin have a relatively short residual activity of 4 weeks [9] [12].

The purpose of this study was a) to determine the benefit of adding a soil-applied grass herbicide to isoxaflutole + metribuzin and b) to develop an understanding of which soil-applied grass herbicides used in combination with isoxaflutole + metribuzin provided the best control of specific annual grass and broadleaf weeds in isoxaflutole-resistant soybean.

\section{Materials and Methods}

\subsection{Study Establishment}

There were nine experiments conducted in 2017 (4 trials) and 2018 (5 trials) in south-western Ontario. The trial sites were located near Exeter, Ennotville, Cambridge and Ridgetown (two sites in 2018). Prior to seeding isoxaflutole-resistant soybean, the land was conventionally tilled. Soybean was planted to a depth of approximately $5 \mathrm{~cm}$, in rows spaced $0.75 \mathrm{~m}$ apart at approximately 372,500 seeds per hectare. Soil characteristics, seeding dates, herbicide application dates and cumulative rainfall 0 to 7 and 0 to 14 days after treatment application (DAA) are presented in Table 1.

Herbicide treatments were arranged in a randomized complete block design with four replications at each site. All plots measured $3 \mathrm{~m}$ wide (4 soybean rows) by 8 or $10 \mathrm{~m}$ long based on available space. Control treatments included an untreated weedy and weedfree plot in each replication. The weedfree control was maintained weedfree with imazethapyr $\left(100 \mathrm{~g} \mathrm{a} \cdot \mathrm{i} \cdot \mathrm{ha}^{-1}\right)$ plus metribuzin $(400 \mathrm{~g}$ $\mathrm{a} \cdot \mathrm{i} \cdot \mathrm{ha}^{-1}$ ) applied PRE followed by glyphosate (900 $\left.\mathrm{g} \mathrm{a} \cdot \mathrm{i} \cdot \mathrm{ha}^{-1}\right)$ applied postemergence (POST) and subsequent hand weeding if required. Herbicide treatments were applied using a $\mathrm{CO}_{2}$ pressurized backpack sprayer calibrated to deliver 200 $\mathrm{L} \cdot \mathrm{ha}^{-1}$ at $240 \mathrm{kPa}$. The sprayer was equipped with a $1.5 \mathrm{~m}$ boom with four Hypro ULD 120-02 nozzles (Pentair, New Brighton, MN) spaced $50 \mathrm{~cm}$ apart resulting in a $2.0 \mathrm{~m}$ spray width. The treatments in this study were applied PRE and included the grass herbicides: pendimethalin (1000 $\left.\mathrm{g} a \cdot \mathrm{i} \cdot \mathrm{ha}^{-1}\right)$, dimethenamid-P (544 $\left.\mathrm{g} \mathrm{a} \cdot \mathrm{i} \cdot \mathrm{ha}^{-1}\right)$, pethoxamid $\left(840 \mathrm{~g} \mathrm{a} \cdot \mathrm{i} \cdot \mathrm{ha}^{-1}\right)$, pyroxasulfone $\left(125 \mathrm{~g} \mathrm{a} \cdot \mathrm{i} \cdot \mathrm{ha}^{-1}\right)$ and S-metolachlor $\left(1050 \mathrm{~g} \mathrm{a} \cdot \mathrm{i} \cdot \mathrm{ha}^{-1}\right)$. Isoxaflutole + metribuzin was applied at three different rates: $52.5+210,79+315$ and $105+420 \mathrm{~g} \mathrm{a} \cdot \mathrm{i} \cdot \mathrm{ha}^{-1}$ hereafter referred to as low, medium and high rates, respectively and the grass herbicides applied with the low rate of isoxaflutole + metribuzin.

\subsection{Data Collected}

Soybean injury was evaluated 1, 2 and 4 weeks after soybean emergence (WAE) on a scale of 0 to 100 , where 0 represented no injury and 100 was recorded when the soybean was dead. At 4, 8 and 12 weeks after application (WAA), visible control of naturally occurring weed species was evaluated on a scale of 0 to 100 with 0 being assigned when treatments provided no control relative to the 
Table 1. Soil characteristics, planting date, application date, and rainfall 7 and 14 days after treatment application (DAA) of 9 trials conducted in southwestern Ontario, Canada in 2017 and 2018.

\begin{tabular}{|c|c|c|c|c|c|c|c|c|c|c|c|c|c|}
\hline$\#$ & Location & Year & Soil Type & Sand & Silt & Clay & $\mathrm{OM}$ & $\mathrm{pH}$ & CEC & $\begin{array}{l}\text { Planting } \\
\text { Date }\end{array}$ & $\begin{array}{l}\text { Application } \\
\text { Date PRE }\end{array}$ & $\begin{array}{c}\text { Rainfall } \\
7 \text { DAA }\end{array}$ & $\begin{array}{l}\text { Rainfall } \\
14 \text { DAA }\end{array}$ \\
\hline & & & & $\%$ & $\%$ & $\%$ & $\%$ & & meq $100 \mathrm{~g}^{-1}$ & & & $\mathrm{~mm}$ & $\mathrm{~mm}$ \\
\hline 1 & Ridgetown & 2018 & Clay Loam & 35 & 30 & 35 & 4.2 & 6.7 & 19 & May 25 & May 29 & 5.0 & 7.3 \\
\hline 2 & Ridgetown & 2017 & Clay Loam & 41 & 28 & 31 & 4.0 & 7.1 & 14 & June 2 & June 7 & 2.7 & 24.8 \\
\hline 3 & Ridgetown & 2018 & Clay Loam & 43 & 26 & 31 & 3.6 & 6.8 & 16 & May 31 & June 1 & 4.9 & 7.2 \\
\hline 4 & Exeter & 2018 & Loam & 41 & 35 & 24 & 2.9 & 7.7 & 27 & May 18 & May 22 & 5.2 & 14.7 \\
\hline 5 & Exeter & 2017 & Loam & 35 & 43 & 22 & 3.9 & 7.8 & 30 & June 3 & June 5 & 0.8 & 12.5 \\
\hline 6 & Ennotville & 2017 & Silt Loam & 41 & 52 & 7 & 3.8 & 7.8 & 18 & May 31 & June 2 & 9.8 & 22.7 \\
\hline 7 & Ennotville & 2018 & Silt Loam & 41 & 52 & 7 & 3.8 & 7.8 & 18 & May 25 & May 28 & 14.9 & 15.8 \\
\hline 8 & $\begin{array}{l}\text { Cam- } \\
\text { bridge }\end{array}$ & 2017 & $\begin{array}{l}\text { Sandy } \\
\text { Loam }\end{array}$ & 68 & 26 & 6 & 2.2 & 7.2 & 9 & May 31 & June 2 & 5.9 & 7.3 \\
\hline 9 & $\begin{array}{l}\text { Cam- } \\
\text { bridge }\end{array}$ & 2018 & $\begin{array}{l}\text { Sandy } \\
\text { Loam }\end{array}$ & 68 & 26 & 6 & 2.2 & 7.2 & 9 & May 25 & May 28 & 10.8 & 14.0 \\
\hline
\end{tabular}

weedy control and 100 assigned when all weeds of the species evaluated were completely dead. At 8 WAA, weed density was determined for each species by counting the number of individual plants within two $0.5 \mathrm{~m}^{2}$ quadrats per plot. The weeds in the quadrats were cut at the soil surface and placed by species in paper bags, which were dried at $60^{\circ} \mathrm{C}$ until constant moisture and then dry weight (biomass) was recorded. Soybean yield was measured at maturity by harvesting the centre two rowsof each plot with a small-plot research combine; yield was adjusted to $13 \%$ moisture.

\subsection{Statistical Analysis}

Data were analyzed in SAS software (ver. 9.4., SAS Institute, Inc., Cary, NC) using the GLIMMIX procedure. When analyzing injury, weed control and yield sites were sorted into groups based on a Tukey-Kramer multiple means comparison test when there was a significant site by treatment interaction using a mixed model where the fixed effects were site, treatment and site by treatment and the random effects were replication within site. Site groupings from weed control at 4 WAA were kept constant throughout control ratings at 8 and 12 WAA, in addition to density and biomass for each species. If the site by treatment interaction was not significant all sites were pooled. When data were pooled across sites, the treatments were considered a fixed effect and the random effects include site, site by treatment and replication within site. An F-test was performed to test the significance of fixed effects and a Wald test was conducted to test the significance of random effects. Residual plots were used to confirm the assumptions that the variances were randomly distributed, independent and homogenous across treatments. Additionally, a Shapiro-Wilk test was performed to test the assumption of normally distributed residuals as described by Shapiro and 
Wilk in 1965 [13]. Natural log and arcsine square root transformations were used when necessary to normalize data; transformed means were transformed back to the original scale for presentation of results. A Tukey-Kramer test was conducted to compare means at a confidence level of 0.05 .

\section{Results and Discussion}

Although weed control was visually assessed at 4, 8 and 12 WAA, only the 12 WAA assessments are presented in Tables 3-10 to minimize the number of tables in the manuscript.

\subsection{Soybean Injury}

At 1 WAE, no soybean injury was visually evident from any of the herbicides applied (Table 2). At 2 WAE, soybean at sites 2, 4, 5, 6, 7 and 9 displayed leaf deformity injury, resembling soybean drawstring symptoms typical of Group 15 herbicides. There was a significant site by treatment interaction (data not shown); site 9 was analyzed independently and the remaining sites were pooled together. At sites 2, 4, 5, 6 and 7, isoxaflutole + metribuzin at all three rates did not cause soybean injury. Pendimethalin, dimethenamid-P, pethoxamid, pyroxasulfone and S-metolachlor, with and without isoxaflutole + metribuzin caused $\leq$ $3 \%$ soybean injury. There was no difference in soybean injury among the five soil-applied grass herbicides. At site 9, higher levels of injury were observed. At 2 WAE, pendimethalin, dimethenamid-P, pethoxamid, pyroxasulfone and S-metolachlor caused $18 \%, 5 \%, 7 \%, 2 \%$ and $11 \%$ soybean leaf deformity, respectively. There was no statistical increase in soybean injury with the addition of isoxaflutole + metribuzin to the grass herbicides evaluated.

At $4 \mathrm{WAE}$, the herbicides caused soybean leaf deformity and bleaching of the foliage at some locations. Leaf deformity occurred at sites 1, 4, 5, 6, 7, 8 and 9. Due to a significant site by treatment interaction (data not shown), site 6 was analyzed separately. At sites 1, 4, 5, 7, 8 and 9, pendimethalin, S-metolachlor and pendimethalin, dimethenamid-P and S-metolachlor with the addition of isoxaflutole + metribuzin caused $1 \%$ soybean injury (Table 2 ). At site 6 , higher levels of injury occurred; pendimethalin, dimethenamid-P, pethoxamid, pyroxasulfone and S-metolachlor caused 16\%, 2\%,3\%, 4\% and 11\% leaf deformity, respectively. There was no statistical increase in soybean leaf deformity when isoxaflutole + metribuzin were added to the soil-applied grass herbicides. Soybean leaf bleaching injury occurred at sites $1,2,3,5,6$ and 8 . There was a significant site by treatment interaction (data not shown); therefore, sites 5 and 8 were analyzed independently and the remaining sites were pooled. At sites 1, 2, 3 and 6, isoxaflutole + metribuzin at the low, medium and high rate caused $1 \%, 2 \%$ and $4 \%$ soybean bleaching, respectively. There was no increase in soybean leaf bleaching when a grass herbicide was added to isoxaflutole + metribuzin. At site 8 , soybean was injured more by isoxaflutole + metribuzin. The low, medium and high rates caused $7 \%, 10 \%$ and $13 \%$ injury, respectively. The grass herbicides plus 
Table 2. Visible soybean injury symptoms at 1,2 and 4 WAE from 9 field experiments in Ontario, Canada in 2017 and 2018.

\begin{tabular}{|c|c|c|c|c|c|c|c|c|c|}
\hline \multirow[b]{2}{*}{ Treatment } & \multirow[b]{2}{*}{ Rate } & \multicolumn{2}{|c|}{$1 \mathrm{WAE}$} & \multicolumn{2}{|c|}{$2 \mathrm{WAE}$} & \multirow[b]{2}{*}{ Site 6} & \multicolumn{3}{|c|}{$4 \mathrm{WAE}$} \\
\hline & & $\begin{array}{c}\text { All } \\
\text { sites }\end{array}$ & $\begin{array}{c}\text { Sites } 2,4 \text {, } \\
5,6,7\end{array}$ & $\begin{array}{c}\text { Sites } \\
9\end{array}$ & $\begin{array}{c}\text { Sites } 1,4 \text {, } \\
5,7,8,9\end{array}$ & & $\begin{array}{c}\text { Site } \\
1,2,3,6\end{array}$ & $\begin{array}{c}\text { Site } \\
8\end{array}$ & $\begin{array}{c}\text { Site } \\
5\end{array}$ \\
\hline & \multicolumn{2}{|l|}{$\mathrm{g} \mathrm{a} \cdot \mathrm{i} \cdot \mathrm{ha}^{-1}$} & \multicolumn{4}{|c|}{$\%$ Leaf deformity injury } & \multicolumn{3}{|c|}{$\%$ Bleaching injury } \\
\hline Pendimethalin & 1000 & 0 & $1 \mathrm{abc}$ & $18 \mathrm{fg}$ & $1 b$ & $16 \mathrm{~d}$ & $0 \mathrm{a}$ & $0 \mathrm{a}$ & $0 \mathrm{a}$ \\
\hline Dimethenamid-P & 544 & 0 & $2 a b c$ & $5 \mathrm{bcd}$ & $0 \mathrm{ab}$ & $2 \mathrm{ab}$ & $0 \mathrm{a}$ & $0 \mathrm{a}$ & $0 \mathrm{a}$ \\
\hline Pethoxamid & 840 & 0 & $1 \mathrm{abc}$ & $7 \mathrm{cde}$ & $0 \mathrm{ab}$ & $3 a b c$ & $0 \mathrm{a}$ & $0 \mathrm{a}$ & $0 \mathrm{a}$ \\
\hline Pyroxasulfone & 125 & 0 & $1 \mathrm{abc}$ & $2 b$ & $0 \mathrm{ab}$ & $4 \mathrm{bc}$ & $0 \mathrm{a}$ & $0 \mathrm{a}$ & $0 \mathrm{a}$ \\
\hline S-metolachlor & 1050 & 0 & $2 b c$ & $11 \mathrm{def}$ & $1 \mathrm{ab}$ & $11 \mathrm{~cd}$ & $0 \mathrm{a}$ & $0 \mathrm{a}$ & $0 \mathrm{a}$ \\
\hline Isoxaflutole + Metribuzin & $52.5+210$ & 0 & $0 \mathrm{a}$ & $0 \mathrm{a}$ & $0 \mathrm{a}$ & $0 \mathrm{a}$ & $1 b c d$ & $7 a b c$ & $16 \mathrm{~b}$ \\
\hline Isoxaflutole + Metribuzin & $79+315$ & 0 & $0 \mathrm{a}$ & $0 \mathrm{a}$ & $0 \mathrm{a}$ & $0 \mathrm{a}$ & $2 \mathrm{~cd}$ & $10 \mathrm{bc}$ & $25 \mathrm{c}$ \\
\hline Isoxaflutole + Metribuzin & $105+420$ & 0 & $0 \mathrm{a}$ & $0 \mathrm{a}$ & $0 \mathrm{a}$ & $0 \mathrm{a}$ & $4 \mathrm{~d}$ & $13 c$ & $30 \mathrm{c}$ \\
\hline Pendimethalin + Isoxaflutole + Metribuzin & $1000+52.5+210$ & 0 & $2 \mathrm{abc}$ & $20 f$ & $1 b$ & $14 \mathrm{~d}$ & $0 \mathrm{abc}$ & $7 \mathrm{abc}$ & $15 b$ \\
\hline Dimethenamid-P + Isoxaflutole + Metribuzin & $544+52.5+210$ & 0 & $2 \mathrm{abc}$ & $4 \mathrm{bc}$ & $1 \mathrm{ab}$ & $0 \mathrm{a}$ & $2 \mathrm{~cd}$ & $5 \mathrm{ab}$ & $15 b$ \\
\hline Pethoxamid + Isoxaflutole + Metribuzin & $840+52.5+210$ & 0 & $1 \mathrm{abc}$ & $4 \mathrm{bc}$ & $0 \mathrm{ab}$ & $6 \mathrm{bcd}$ & $0 \mathrm{ab}$ & $9 \mathrm{bc}$ & $17 \mathrm{~b}$ \\
\hline Pyroxasulfone + Isoxaflutole + Metribuzin & $125+52.5+210$ & 0 & $1 \mathrm{abc}$ & $3 \mathrm{bc}$ & $0 \mathrm{ab}$ & $3 a b c$ & $1 \mathrm{abcd}$ & $4 \mathrm{a}$ & $15 b$ \\
\hline S-metolachlor + Isoxaflutole + Metribuzin & $1050+52.5+210$ & 0 & $3 c$ & $13 \mathrm{efg}$ & $1 \mathrm{ab}$ & $11 \mathrm{~cd}$ & $0 a b c$ & $5 \mathrm{ab}$ & $17 \mathrm{~b}$ \\
\hline
\end{tabular}

Note: Means followed by the same letter within a column are not statistically different according to the Tukey-Kramer multiple range test at $p<0.05$.

isoxaflutole + metribuzin caused $4 \%$ to $9 \%$ bleaching injury, which was similar toisoxaflutole + metribuzin. At site 5, isoxaflutole + metribuzin at the low medium and high rate caused $16 \%, 25 \%$ and $30 \%$ soybean bleaching, respectively. The grass herbicides plus isoxaflutole + metribuzin caused $15 \%$ to $17 \%$ soybean bleaching, similar to isoxaflutole + metribuzin.

Soybean displayed the most sensitivity to pendimethalin and S-metolachlor. Rainfall after application appeared to influence the level of soybean leaf deformity at the various sites. Soybean at sites with more rainfall after application displayed more severe leaf deformity compared to sites receiving less rainfall. This was probably due to higher herbicide uptake in soybean with higher rainfall. Based on visible observations in the field, as soybean continued to grow, the leaf deformity injury occurred on the first 3 trifoliate leaves with no leaf deformity observed on new soybean growth after the third trifoliate.

Soybean leaf bleaching symptoms were observed at $4 \mathrm{WAE}$ on the $3^{\text {rd }}$ and $4^{\text {th }}$ trifoliate leaves. This injury appeared to be influenced by rainfall received 14 to 21 DAA. Soybean injury ( $\leq 30 \%$ ) was observed at sites $1,2,3,5,6$ and 8 which received 12.3 to $43.5 \mathrm{~mm}$ of rain in the 21 days after herbicide application; in contrast sites 4, 7 and 9 received $<3 \mathrm{~mm}$ of rain in the 21 days after application and no soybean injury was observed. Rainfall during this period of time after herbicide application probably dissolved the herbicides into soil water solution, allowing for the absorption by the soybean, resulting in a higher herbicide concentration within the plant which the soybean could not metabolize quickly 
enough to avoid herbicide injury. Bleaching symptoms were evident one week later when injury was evaluated. As the $5^{\text {th }}$ trifoliate leaves were emerging, no bleaching symptoms were present at any sites, as the soybean was probably able to metabolize isoxaflutole by that time.

\subsection{Common Lambsquarters}

Common lambsquarters control was assessed at seven sites in this study. A significant treatment by site interaction occurred for common lambsquarters control (data not shown); therefore, results from sites 2 and 4 were combined, sites 3, 5, 8 and 9 were combined and site 7 was analyzed separately (Table 3 ).

At $12 \mathrm{WAA}$, at sites 2 and 4, pendimethalin, dimethenamid-P, pethoxamid, pyroxasulfone and S-metolachlor controlled common lambsquarters $4 \%$ to $23 \%$ (Table 3). These treatments did not differ from one another. Isoxaflutole + metribuzin at the low, medium and high rate controlled common lambsquarters $37 \%, 68 \%$ and $86 \%$, respectively. There was no difference in common lambsquarters control among the three rates of isoxaflutole + metribuzin; however, the medium and high rate provided as much as $82 \%$ higher control than dimethenamid-P, pyroxasulfone and S-metolachlor. Pendimethalin, dimethenamid-P, pethoxamid, pyroxasulfone, or S-metolachlor plus isoxaflutole + metribuzin controlled common lambsquarters $41 \%$ to $68 \%$. There were no differences in common lambsquarters control between these treatments and isoxaflutole + metribuzin applied at the low, medium or high rate or the corresponding grass herbicides applied alone. At sites 3, 5, 8 and 9, pendimethalin, dimethenamid-P, pethoxamid, pyroxasulfone and S-metolachlor controlled common lambsquarters $24 \%$ to $58 \%$. Isoxaflutole + metribuzin at the low, medium and high rate provided $94 \%, 99 \%$ and $100 \%$ control, respectively. Isoxaflutole + metribuzin provided greater control than all the grass herbicides applied alone with the exception of pendimethalin. Pendimethalin, dimethenamid-P, pethoxamid, pyroxasulfone, or S-metolachlor plus isoxaflutole + metribuzin provided 99\%, $94 \%, 97 \%, 93 \%$ and $94 \%$ common lambsquarters control, respectively. All grass herbicides with the exception of pendimethalin, benefitted from the addition of isoxaflutole + metribuzin in the tank-mix. At site 7, pendimethalin, dimethenamid-P, pethoxamid, pyroxasulfone and S-metolachlor controlled common lambsquarters $91 \%, 85 \%, 85 \%, 93 \%$ and $67 \%$, respectively. Isoxaflutole + metribuzin at each rate as well as the tank-mix of the grass herbicides with isoxaflutole + metribuzin provided $100 \%$ control of common lambsquarters. The addition of isoxaflutole + metribuzin to dimethenamid-P, pethoxamid, or S-metolachlor improved common lambsquarters control 15\%,15\% and 33\%, respectively.

At 8 WAA, at all three site groupings, common lambsquarters density was reduced with application of pendimethalin, isoxaflutole + metribuzin at the low, medium or high rate, or any grass herbicide with the addition of isoxaflutole + metribuzin compared to the untreated control (Table 3). In contrast, dimethenamid-P, pethoxamid, pyroxasulfone and S-metolachlor did not reduce 
Table 3. Common lambsquarters control at 12 WAA and density and biomass at 8 WAA from 7 field experiments conducted in Ontario, Canada in 2017 and $2018^{\mathrm{a}}$.

\begin{tabular}{|c|c|c|c|c|c|c|c|c|c|c|}
\hline \multirow{3}{*}{ Treatment } & \multirow{3}{*}{ Rate } & \multicolumn{3}{|c|}{ Control 12 WAA } & \multicolumn{3}{|c|}{ Density } & \multicolumn{3}{|c|}{ Biomass } \\
\hline & & Sites & Sites & Site & Sites & Sites & Site & Sites & Sites & Site \\
\hline & & 2,4 & $3,5,8,9$ & 7 & 2,4 & $3,5,8,9$ & 7 & 2,4 & $3,5,8,9$ & 7 \\
\hline & $\mathrm{g} \mathrm{a} \cdot \mathrm{i} \cdot \mathrm{ha}^{-1}$ & \multicolumn{3}{|c|}{$\%$} & \multicolumn{3}{|c|}{$\# \mathrm{~m}^{-2}$} & \multicolumn{3}{|c|}{$\mathrm{g} \cdot \mathrm{m}^{-2}$} \\
\hline Untreated Control & & & & & $32.5 \mathrm{~d}$ & $21.5 \mathrm{e}$ & $2.5 b$ & $31.4 \mathrm{a}$ & $16.5 \mathrm{abc}$ & $8.6 \mathrm{bc}$ \\
\hline Dimethenamid-P & 544 & $6 \mathrm{~cd}$ & $25 b$ & $85 b$ & $14.8 \mathrm{~cd}$ & 15.0de & $0.7 \mathrm{ab}$ & $24.9 \mathrm{a}$ & $24.5 c$ & 6.abc \\
\hline Pethoxamid & 840 & $11 \mathrm{bcd}$ & $26 b$ & $85 b$ & $8.1 \mathrm{bcd}$ & $10.0 \mathrm{de}$ & $1.3 \mathrm{ab}$ & $22.7 \mathrm{a}$ & $15.7 \mathrm{abc}$ & $3.3 \mathrm{abc}$ \\
\hline Pyroxasulfone & 125 & $7 \mathrm{~cd}$ & $34 \mathrm{~b}$ & $93 \mathrm{ab}$ & $14.2 \mathrm{~cd}$ & $7.0 \mathrm{cde}$ & $0.4 \mathrm{ab}$ & $50.6 a$ & $18.8 \mathrm{bc}$ & $1.3 \mathrm{abc}$ \\
\hline S-metolachlor & 1050 & $4 d$ & $24 \mathrm{~b}$ & $67 b$ & $12.1 \mathrm{~cd}$ & $19.8 \mathrm{de}$ & $2.7 b$ & $25.1 \mathrm{a}$ & $22.9 c$ & $14.5 \mathrm{c}$ \\
\hline Isoxaflutole + Metribuzin & $79+315$ & $68 \mathrm{ab}$ & $99 \mathrm{a}$ & $100 \mathrm{a}$ & $2.4 \mathrm{ab}$ & $0.6 \mathrm{ab}$ & $0.2 \mathrm{a}$ & $4.9 \mathrm{a}$ & $1.3 \mathrm{abc}$ & $0.8 \mathrm{ab}$ \\
\hline Isoxaflutole + Metribuzin & $105+420$ & $86 a$ & $100 \mathrm{a}$ & $100 \mathrm{a}$ & $1.3 \mathrm{a}$ & $0.2 \mathrm{a}$ & $0.02 \mathrm{a}$ & $2.0 \mathrm{a}$ & $0.7 \mathrm{a}$ & $0.1 \mathrm{a}$ \\
\hline Pendimethalin + Isoxaflutole + Metribuzin & $1000+52.5+210$ & $68 \mathrm{ab}$ & $99 a$ & $100 \mathrm{a}$ & $2.0 \mathrm{ab}$ & $0.7 \mathrm{ab}$ & $0.02 \mathrm{a}$ & $2.3 \mathrm{a}$ & $0.8 \mathrm{ab}$ & $0.1 \mathrm{a}$ \\
\hline Dimethenamid-P + Isoxaflutole + Metribuzin & $544+52.5+210$ & $57 \mathrm{abcd}$ & $94 a$ & $100 \mathrm{a}$ & $2.1 \mathrm{ab}$ & $1.4 \mathrm{abc}$ & $0.02 \mathrm{a}$ & $6.5 \mathrm{a}$ & $5.6 \mathrm{abc}$ & $0.1 \mathrm{a}$ \\
\hline Pethoxamid + Isoxaflutole + Metribuzin & $840+52.5+210$ & $60 \mathrm{abc}$ & $97 \mathrm{a}$ & $100 \mathrm{a}$ & $4.3 \mathrm{abc}$ & $1.1 \mathrm{abc}$ & $0.04 \mathrm{a}$ & $6.5 \mathrm{a}$ & $3.7 \mathrm{abc}$ & $0.1 \mathrm{a}$ \\
\hline Pyroxasulfone + Isoxaflutole + Metribuzin & $125+52.5+210$ & $57 \mathrm{abcd}$ & $93 a$ & $100 \mathrm{a}$ & $4.2 \mathrm{abc}$ & $0.9 \mathrm{ab}$ & $0.02 \mathrm{a}$ & $10.0 \mathrm{a}$ & $2.9 \mathrm{abc}$ & $0.1 \mathrm{a}$ \\
\hline S-metolachlor + Isoxaflutole + Metribuzin & $1050+52.5+210$ & $41 \mathrm{abcd}$ & $94 a$ & $100 \mathrm{a}$ & 3.6abc & $1.3 \mathrm{abc}$ & $0.02 \mathrm{a}$ & $9.9 \mathrm{a}$ & $2.1 \mathrm{abc}$ & $0.1 \mathrm{a}$ \\
\hline
\end{tabular}

${ }^{a}$ Means followed by the same letter within a column are not statistically different according to the Tukey-Kramer multiple range test at $p<0.05$.

common lambsquarters density compared to the untreated control. At site 2 and 4 , the above-mentioned herbicide treatments reduced common lambsquarters density 83 to $96 \%$. There was no difference in common lambsquarters density among pendimethalin, dimethenamid-P, pethoxamid, pyroxasulfone, S-metolachlor, the low rate of isoxaflutole + metribuzin or the combination of pethoxamid, pyroxasulfone or S-metolachlor with the addition of isoxaflutole + metribuzin. At sites 3, 5, 8 and 9, the above-mentioned herbicide treatments reduced common lambsquarters density $79 \%$ to $99 \%$. Isoxaflutole + metribuzin reduced common lambsquarters density $20 \%$ more than pendimethalin. The addition of isoxaflutole + metribuzin to dimethenamid-P, pethoxamid, pyroxasulfone and S-metolachlor reduced common lambsquarters density 63\%, 41\%, 29\% and $86 \%$ more than the grass herbicides applied alone, respectively. At site 7 there was a $92 \%$ to $99 \%$ reduction in common lambsquarters density with the above mentioned herbicide treatments compared to the untreated control. Pendimethalin, all three rates of isoxaflutole + metribuzin and the grass herbicides + isoxaflutole + metribuzin reduced density compared to the untreated control and S-metolachlor.

At 8 WAA, at sites 2 and 4 and sites 3, 5, 8 and 9, common lambsquarters biomass was not reduced significantly with any herbicide treatment compared to the untreated control (Table 3). However, at sites 3, 5, 8 and 9, isoxaflutole + 
metribuzin at the high rate reduced common lambsquarters biomass compared to dimethenamid-P, pyroxasulfone and S-metolachlor. At site 7, isoxaflutole + metribuzin at the low and high rate and all the grass herbicides + isoxaflutole + metribuzin decreased common lambsquarters biomass 99\%. Additionally, those treatments decreased common lambsquarters biomass more than S-metolachlor.

In summary, common lambsquarters control was influenced by rainfall and weed density. Site 7 , which received $14.9 \mathrm{~mm}$ of rainfall within 7 DAA and had the lowest common lambsquarters density and the highest level of common lambsquarters control. Sites 3, 5, 8 and 9, received 0.8 to $10.8 \mathrm{~mm}$ of rainfall 0 to 7 DAA; this probably was sufficient rainfall for the herbicide to be dissolved in soil water solution so that it could be taken up by weed seedlings. Site 5 received only $0.8 \mathrm{~mm}$ which would likely not be enough rain to activate the herbicide; it also may not be enough rain to allow for weeds to germinate. This site had delayed germination; therefore, after the rainfall 7 to $14 \mathrm{DAA}$, the herbicide was activated and controlled the late emerging weeds. The selectivity of each herbicide is highlighted in this group of sites; although, pendimethalin has very low water solubility $\left(0.275 \mathrm{mg} \cdot \mathrm{L}^{-1}\right)$, it still provided greater common lambsquarters control than the Group 15 herbicides. Chomas and Kells [14] reported similar results where pendimethalin and metolachlor controlled common lambsquarters 91 and $0 \%$, respectively, in a year with limited activating rainfall compared to 98 to 100 and $50 \%$ to $75 \%$ control, respectively, in years when higher levels of rain occurred. Sites 2 and 4 received only 2.7 and $5.2 \mathrm{~mm}$ of rainfall 0 to 7 DAA, which reduced common lambsquarters control with all of the herbicides evaluated. Overall, isoxaflutole + metribuzin at the medium and high rate provided the highest level of common lambsquarters control. The grass herbicide which provided the highest common lambsquarters control was pendimethalin; however, the addition of pendimethalin to isoxaflutole + metribuzin only increased control early in the season when limited rainfall occurred compared to isoxaflutole + metribuzin alone at the low rate.

\subsection{Pigweed Spp.}

Redroot pigweed (Amaranthus retroflexus L.) and green pigweed (Amaranthus powellii S. Watson) were combined during evaluations. Pigweed spp. were assessed at 7 sites in this study and due to a significant treatment by site interaction, sites were separated (data not shown); sites 2 and 4 were combined and sites 3, 6, 7, 8 and 9 were combined for analysis (Table 4).

At $12 \mathrm{WAA}$, at sites 2 and 4, pendimethalin, dimethenamid-P, pethoxamid, pyroxasulfone and S-metolachlor controlled pigweed spp. 4\%, 10\%, 13\%, 32\% and $6 \%$, respectively (Table 4 ). The grass herbicides provided similar control of pigweed spp. Isoxaflutole + metribuzin at the low, medium and high rate controlled pigweed spp. $27 \%, 59 \%$ and $81 \%$, respectively; there was no difference among rates. Isoxaflutole + metribuzin at the medium rate provided $53 \%$ and $55 \%$ higher pigweed spp. Control than pendimethalin and S-metolachlor, respectively. Isoxaflutole + metribuzin at the high rate provided $68 \%$ to $77 \%$ 
Table 4. Pigweed control at 12 WAA and density and biomass at 8 WAA from 7 field experiments conducted in Ontario, Canada in 2017 and $2018^{\mathrm{a}}$.

\begin{tabular}{|c|c|c|c|c|c|c|c|}
\hline \multirow{3}{*}{ Treatment } & \multirow{3}{*}{ Rate } & \multicolumn{2}{|c|}{ Control 12 WAA } & \multicolumn{2}{|c|}{ Density } & \multicolumn{2}{|c|}{ Biomass } \\
\hline & & Sites & Sites & Sites & Sites & Sites & Sites \\
\hline & & 2,4 & $3,6,7,8,9$ & 2,4 & $3,6,7,8,9$ & 2,4 & $3,6,7,8,9$ \\
\hline & $\mathrm{g} \mathrm{a} \cdot \mathrm{i} \cdot \mathrm{ha}^{-1}$ & \multicolumn{2}{|c|}{$\%$} & \multicolumn{2}{|c|}{$\# \mathrm{~m}^{-2}$} & \multicolumn{2}{|c|}{$g \cdot \mathrm{m}^{-2}$} \\
\hline Untreated Control & & & & $33.7 \mathrm{a}$ & $23.2 \mathrm{~d}$ & $183.8 \mathrm{ab}$ & $40.3 \mathrm{e}$ \\
\hline Dimethenamid-P & 544 & $10 \mathrm{~cd}$ & $70 \mathrm{~cd}$ & $25.5 \mathrm{a}$ & $3.9 \mathrm{abc}$ & $140.4 \mathrm{ab}$ & 10.5 bcde \\
\hline Pethoxamid & 840 & $13 \mathrm{bcd}$ & $52 d$ & $33.1 \mathrm{a}$ & $7.9 \mathrm{bcd}$ & $123.2 \mathrm{ab}$ & $22.5 \mathrm{de}$ \\
\hline Pyroxasulfone & 125 & $32 \mathrm{abcd}$ & $85 \mathrm{bc}$ & $32.3 \mathrm{a}$ & $3.4 \mathrm{abc}$ & $93.8 \mathrm{ab}$ & 4.7abcde \\
\hline S-metolachlor & 1050 & $6 \mathrm{~d}$ & $66 \mathrm{~cd}$ & $33.2 \mathrm{a}$ & $8.7 \mathrm{bcd}$ & $130.4 \mathrm{ab}$ & $16.2 \mathrm{cde}$ \\
\hline Isoxaflutole + Metribuzin & $79+315$ & $59 \mathrm{abc}$ & $95 \mathrm{ab}$ & $15.6 \mathrm{a}$ & $0.6 \mathrm{a}$ & $61.5 \mathrm{ab}$ & $1.1 \mathrm{ab}$ \\
\hline Isoxaflutole + Metribuzin & $105+420$ & $81 \mathrm{a}$ & $97 \mathrm{ab}$ & $7.3 \mathrm{a}$ & $0.4 \mathrm{a}$ & $25.4 \mathrm{a}$ & $1.2 \mathrm{ab}$ \\
\hline Pendimethalin + Isoxaflutole + Metribuzin & $1000+52.5+210$ & $65 \mathrm{ab}$ & $95 \mathrm{ab}$ & $13.1 \mathrm{a}$ & $0.8 \mathrm{a}$ & $51.8 \mathrm{ab}$ & $2.2 \mathrm{abc}$ \\
\hline Dimethenamid-P + Isoxaflutole + Metribuzin & $544+52.5+210$ & $54 \mathrm{abcd}$ & $98 \mathrm{ab}$ & $12.7 \mathrm{a}$ & $0.2 \mathrm{a}$ & $70.6 \mathrm{ab}$ & $0.4 \mathrm{a}$ \\
\hline Pethoxamid + Isoxaflutole + Metribuzin & $840+52.5+210$ & $48 \mathrm{abcd}$ & $97 \mathrm{ab}$ & $11.7 \mathrm{a}$ & $0.5 \mathrm{a}$ & $38.7 \mathrm{ab}$ & $1.2 \mathrm{ab}$ \\
\hline Pyroxasulfone + Isoxaflutole + Metribuzin & $125+52.5+210$ & $67 \mathrm{ab}$ & $99 \mathrm{a}$ & $14.3 \mathrm{a}$ & $0.5 \mathrm{a}$ & $54.7 \mathrm{ab}$ & $0.8 \mathrm{ab}$ \\
\hline S-metolachlor + Isoxaflutole + Metribuzin & $1050+52.5+210$ & $38 \mathrm{abcd}$ & $98 \mathrm{ab}$ & $16.5 \mathrm{a}$ & $0.7 \mathrm{a}$ & $72.3 \mathrm{ab}$ & $1.3 \mathrm{ab}$ \\
\hline
\end{tabular}

${ }^{a}$ Means followed by the same letter within a column are not statistically different according to the Tukey-Kramer multiple range test at $p<0.05$.

higher pigweed spp. control than pendimethalin, dimethenamid-P, pethoxamid and S-metolachlor. Pendimethalin, dimethenamid-P, pethoxamid, pyroxasulfone and S-metolachlor with the addition of isoxaflutole + metribuzin controlled pigweed spp. $38 \%$ to $67 \%$; there was no difference in control among the grass herbicides. The addition of isoxaflutole + metribuzin to pendimethalin increased pigweed spp. control $61 \%$ compared to pendimethalin applied alone. At sites 2 and 4 , there was no increase in pigweed spp. control when a grass herbicide was added to isoxaflutole + metribuzin. This was expected as these herbicides generally do not control broadleaved weeds such as pigweed species. At sites 3, 6, 7, 8 and 9, pendimethalin, dimethenamid-P, pethoxamid, pyroxasulfone and S-metolachlor controlled pigweed spp. $63 \%, 70 \%, 52 \%, 85 \%$ and $66 \%$, respectively. Pyroxasulfone provided greater control than pethoxamid; all other grass herbicides provided similar pigweed spp. control. Isoxaflutole + metribuzin at the varying rates provided $93 \%$ to $97 \%$ control and did not differ among rates. Isoxaflutole + metribuzin provided greater pigweed spp. control than the grass herbicides with the exception ofpyroxasulfone. Pendimethalin, dimethenamid-P, pethoxamid, pyroxasulfone, or S-metolachlor applied in a tank-mix with isoxaflutole + metribuzin controlled pigweed spp. $95 \%$ to $99 \%$. The addition of isoxaflutole + metribuzin to the grass herbicides increased control compared to the respective grass herbicide applied alone. There was no improvement in pigweed 
spp. control with the addition of a grass herbicide to isoxaflutole + metribuzin.

At $8 \mathrm{WAA}$, at sites 2 and 4, no herbicide treatment reduced pigweed spp. density compared to the untreated control and there was no difference in pigweed spp. density among the herbicide treatments evaluated (Table 4). At sites 3, 6, 7, 8 and 9 , dimethenamid-p, pyroxasulfone, isoxaflutole + metribuzin at all three rates and the tank-mixtures of a grass herbicides plus isoxaflutole + metribuzin reduced pigweed density 83 to $99 \%$ compared to the untreated control. Isoxaflutole + metribuzin at the low rate, dimethenamid-P, pethoxamid, pyroxasulfone and S-metolachlor reduced pigweed spp. density similarly; isoxaflutole + metribuzin reduced pigweed density $61 \%$ more than pendimethalin. Pendimethalin, pethoxamid or S-metolachlor plus isoxaflutole + metribuzin provided 65, 32 and $34 \%$ greater reduction in density compared to the respective grass herbicide applied alone. The addition of isoxaflutole + metribuzin to dimethenamid-P orpyroxasulfone did not increase the reduction in pigweed spp. density.

At 8 WAA, at sites 2 and 4, no treatment reduced pigweed spp. biomass compared to the untreated control (Table 4). There were no treatment differences with the exception of isoxaflutole + metribuzin at the high rate provided a greater reduction in pigweed spp. biomass than pendimethalin. At sites 3, 6, 7, 8 and 9 isoxaflutole + metribuzin at the low, medium and high rate and the tank-mixtures of a grass herbicides plus isoxaflutole + metribuzin reduced pigweed spp. biomass $92 \%$ to $99 \%$ compared to the untreated control. The grass herbicides applied alone did not reduce pigweed spp. biomass. The addition of isoxaflutole + metribuzin to pendimethalin, dimethenamid-P, pethoxamid, or S-metolachlor reduced biomass an additional 68\%, 25\%, 53\% and 37\%, respectively, compared to the grass herbicide applied alone. The addition of isoxaflutole + metribuzin to pyroxasulfone did not differ in biomass reduction compared to pyroxasulfone alone. The addition of a grass herbicide to isoxaflutole + metribuzin did not provide an additional reduction in pigweed spp. biomass compared to isoxaflutole + metribuzin applied alone.

In summary, pigweed spp. control was influenced by rainfall after application. Pigweed spp. control was lower at sites 2 and 4 which received 2.7 and $0.8 \mathrm{~mm}$ of rainfall 0 to $7 \mathrm{DAA}$, respectively. In contrast, pigweed spp. control was greater at sites $3,6,7,8$ and 9 which received higher rainfall of 4.9 to $14.9 \mathrm{~mm} 0$ to $7 \mathrm{DAA}$. Of the grass herbicides evaluated, pyroxasulfone provided the highest pigweed spp. control across sites with differing levels of rainfall. Redroot pigweed is very sensitive to pyroxasulfone; rates as low as $93 \mathrm{~g}$ a.i $\cdot \mathrm{ha}^{-1}$ controlled pigweed $90 \%$ [15]. Generally, the addition of pyroxasulfone to isoxaflutole + metribuzin at the low rate improved pigweed control compared to isoxaflutole and metribuzin alone; however, isoxaflutole + metribuzin at the high rate provided better pigweed spp. control than pyroxasulfone + isoxaflutole + metribuzin at the low rate.

\subsection{Common Ragweed}

Common ragweed (Ambrosia artemisiifolia L.) populations were present at sites 1, 3 and 5 in this study (Table 5). There was a significant treatment by site in- 
teraction, each site was analyzed separately (data not shown).

At 12 WAA, at site 1, pendimethalin, dimethenamid-P, pethoxamid, pyroxasulfone and S-metolachlor controlled common ragweed $28 \%$ to $62 \%$; there was no difference in control among the grass herbicides (Table 5). Isoxaflutole + metribuzin at the low, medium and high rate controlled common ragweed $82 \%$, $90 \%$ and $98 \%$, respectively. The high rate provided $70 \%$ and $67 \%$ greater common ragweed control than dimethenamid-P and pethoxamid, respectively. Pendimethalin, dimethenamid-P, pethoxamid, pyroxasulfone, or S-metolachlor plus isoxaflutole + metribuzin controlled common ragweed $66 \%$ to $100 \%$. The grass herbicides plus isoxaflutole + metribuzin did not differ among each other and did not provide any additional control compared to isoxaflutole + metribuzin. The addition of isoxaflutole + metribuzin to dimethenamid-P increased control $72 \%$ compared to dimethenamid-P alone. At site 3, pendimethalin, dimethenamid-P, pethoxamid, pyroxasulfone and S-metolachlor controlled common ragweed $20 \%$ to $54 \%$, there was no difference in common ragweed control among the grass herbicides. Isoxaflutole + metribuzin at the low, medium and high rate controlled common ragweed $97 \%$ to $100 \%$. The addition of a grass herbicide to isoxaflutole + metribuzin did not increase common ragweed control. Similarly, at site 5 , the grass herbicides alone provided less common ragweed control than isoxaflutole + metribuzin at the low, medium and high rate, or any combination of a grass herbicide plus isoxaflutole + metribuzin.

At 8 WAA, at site 1, the herbicide treatments evaluated did not reduce common ragweed density compared to the untreated control (Table 5). Dimethenamid-P+ isoxaflutole + metribuzin reduced density compared to dimethenamid-P or S-metolachlor alone. At site 3, the grass herbicides did not reduce common ragweed density compared to the untreated control; however, isoxaflutole + metribuzin at all three rates and the addition of a grass herbicide to isoxaflutole + metribuzin reduced common ragweed density $98 \%$ to $99 \%$ compared to the untreated control. At site 5, pendimethalin, dimethenamid-P, pethoxamid and S-metolachlor did not reduce common ragweed density compared to the untreated control. Pyroxasulfone reduced common ragweed density 73\%. Pyroxasulfone reduced common ragweed density more than pendimethalin and S-metolachlor; however, it did not differ from dimethenamid-P and pethoxamid. Isoxaflutole + metribuzin at the low, medium and high rate, or any combination of a grass herbicide plus isoxaflutole + metribuzin reduced common ragweed density $96 \%$ to $99 \%$ compared to the untreated control.

At $8 \mathrm{WAA}$, at site 1 , none of the herbicide treatments evaluated reduced common ragweed biomass compared to the untreated control, additionally, there were no treatment differences (Table 5). At site 3, the grass herbicides applied alone, isoxaflutole + metribuzin at the medium rate and pendimethalin, pethoxamid, pyroxasulfone or S-metolachlor plus isoxaflutole + metribuzin did not reduce common ragweed biomass compared to the untreated control. Isoxaflutole + metribuzin at the low and high rate and dimethenamid- $\mathrm{P}+$ isoxaflutole + 
Table 5. Common ragweed control at 12 WAA and density and biomass at 8 WAA from 7 field experiments conducted in Ontario, Canada in 2017 and $2018^{\mathrm{a}}$.

\begin{tabular}{|c|c|c|c|c|c|c|c|c|c|c|}
\hline Treatment & Rate & $\begin{array}{c}\text { Site } \\
1\end{array}$ & $\begin{array}{c}\text { Site } \\
3\end{array}$ & $\begin{array}{c}\text { Site } \\
5\end{array}$ & $\begin{array}{c}\text { Site } \\
1\end{array}$ & $\begin{array}{c}\text { Site } \\
3\end{array}$ & $\begin{array}{c}\text { Site } \\
5\end{array}$ & $\begin{array}{c}\text { Site } \\
1\end{array}$ & $\begin{array}{c}\text { Site } \\
3\end{array}$ & $\begin{array}{c}\text { Site } \\
5\end{array}$ \\
\hline & $\mathrm{g} \mathrm{a} \cdot \mathrm{i} \cdot \mathrm{ha}^{-1}$ & & $\%$ & & & $\# \mathrm{~m}^{-2}$ & & & $g \cdot m^{-2}$ & \\
\hline Untreated Control & & & & & $5.7 \mathrm{ab}$ & $64.8 \mathrm{~b}$ & $74.2 \mathrm{c}$ & $0.5 \mathrm{a}$ & $14.6 \mathrm{bcd}$ & $65.6 \mathrm{~b}$ \\
\hline Pendimethalin & 1000 & $55 \mathrm{abc}$ & $20 \mathrm{~b}$ & $0 \mathrm{~b}$ & $3.5 \mathrm{ab}$ & $71.7 \mathrm{~b}$ & $58.9 c$ & $0.3 \mathrm{a}$ & $31.3 \mathrm{~d}$ & $98.7 b$ \\
\hline Dimethenamid-P & 544 & $28 c$ & $46 \mathrm{~b}$ & $0 \mathrm{~b}$ & $11.0 \mathrm{~b}$ & $50.6 \mathrm{~b}$ & $43.1 \mathrm{bc}$ & $5.8 \mathrm{a}$ & $19.8 \mathrm{~cd}$ & $66.9 \mathrm{~b}$ \\
\hline Pethoxamid & 840 & $31 c$ & $54 \mathrm{~b}$ & $1 b$ & $4.3 \mathrm{ab}$ & $34.4 \mathrm{~b}$ & $38.4 \mathrm{bc}$ & $0.8 \mathrm{a}$ & $9.9 \mathrm{abcd}$ & $46.6 \mathrm{~b}$ \\
\hline Pyroxasulfone & 125 & $62 \mathrm{abc}$ & $45 b$ & $0 \mathrm{~b}$ & $1.1 \mathrm{ab}$ & $28.4 \mathrm{~b}$ & $20.1 b$ & $1.0 \mathrm{a}$ & $17.1 \mathrm{~cd}$ & $45.6 \mathrm{~b}$ \\
\hline S-metolachlor & 1050 & $43 \mathrm{bc}$ & $40 \mathrm{~b}$ & $0 \mathrm{~b}$ & $10.8 \mathrm{~b}$ & $71.2 \mathrm{~b}$ & $79.8 \mathrm{c}$ & $3.7 \mathrm{a}$ & $33.4 \mathrm{~d}$ & $82.4 \mathrm{~b}$ \\
\hline Isoxaflutole + Metribuzin & $52.5+210$ & $82 \mathrm{abc}$ & $97 \mathrm{a}$ & $100 \mathrm{a}$ & $0.4 \mathrm{ab}$ & $0.6 \mathrm{a}$ & $0.01 \mathrm{a}$ & $1.1 \mathrm{a}$ & $0.5 \mathrm{a}$ & $0.02 \mathrm{a}$ \\
\hline Isoxaflutole + Metribuzin & $79+315$ & $90 \mathrm{abc}$ & $99 a$ & $100 \mathrm{a}$ & $0.4 \mathrm{ab}$ & $0.2 \mathrm{a}$ & $0.01 \mathrm{a}$ & $0.2 \mathrm{a}$ & $0.8 \mathrm{ab}$ & $0.02 \mathrm{a}$ \\
\hline Isoxaflutole + Metribuzin & $105+420$ & $98 \mathrm{ab}$ & $100 \mathrm{a}$ & $100 \mathrm{a}$ & $0.4 \mathrm{ab}$ & $0.02 \mathrm{a}$ & $0.01 \mathrm{a}$ & $0.3 \mathrm{a}$ & $0.1 \mathrm{a}$ & $0.02 \mathrm{a}$ \\
\hline Pendimethalin + Isoxaflutole + Metribuzin & $1000+52.5+210$ & $66 \mathrm{abc}$ & $99 a$ & $99 a$ & $0.6 \mathrm{ab}$ & $0.6 \mathrm{a}$ & $0.2 \mathrm{a}$ & $0.8 \mathrm{a}$ & $2.2 \mathrm{abc}$ & $0.1 \mathrm{a}$ \\
\hline Dimethenamid-P + Isoxaflutole + Metribuzin & $544+52.5+210$ & $100 \mathrm{a}$ & $98 a$ & $100 \mathrm{a}$ & $0.1 \mathrm{a}$ & $0.02 \mathrm{a}$ & $0.01 \mathrm{a}$ & $0.1 \mathrm{a}$ & $0.1 \mathrm{a}$ & $0.02 \mathrm{a}$ \\
\hline Pethoxamid + Isoxaflutole + Metribuzin & $840+52.5+210$ & $90 \mathrm{abc}$ & $97 \mathrm{a}$ & $100 \mathrm{a}$ & $0.7 \mathrm{ab}$ & $0.7 \mathrm{a}$ & $0.01 \mathrm{a}$ & $1.3 \mathrm{a}$ & $2.0 \mathrm{abc}$ & $0.02 \mathrm{a}$ \\
\hline Pyroxasulfone + Isoxaflutole + Metribuzin & $125+52.5+210$ & $95 \mathrm{ab}$ & $100 \mathrm{a}$ & $100 \mathrm{a}$ & $1.0 \mathrm{ab}$ & $0.7 \mathrm{a}$ & $0.01 \mathrm{a}$ & $3.2 \mathrm{a}$ & $1.9 \mathrm{abc}$ & $0.02 \mathrm{a}$ \\
\hline S-metolachlor + Isoxaflutole + Metribuzin & $1050+52.5+210$ & $98 \mathrm{ab}$ & $98 \mathrm{a}$ & $98 \mathrm{a}$ & $1.2 \mathrm{ab}$ & $0.2 \mathrm{a}$ & $0.3 \mathrm{a}$ & $0.9 \mathrm{a}$ & $1.3 \mathrm{abc}$ & $0.2 \mathrm{a}$ \\
\hline
\end{tabular}

${ }^{a}$ Means followed by the same letter within a column are not statistically different according to the Tukey-Kramer multiple range test at $p<0.05$.

metribuzin reduced biomass $96 \%$ to $99 \%$ compared to the untreated control. At site 5, the grass herbicides applied alone did not reduce common ragweed biomass relative to the untreated control. Isoxaflutole + metribuzin and the tankmixtures of a grass herbicide plus isoxaflutole + metribuzin reduced common ragweed biomass $99 \%$.

In summary, common ragweed control was influenced by rainfall after application and weed density. Sites 1, 3 and 5 had 5.0, 4.9 and $0.8 \mathrm{~mm}$ of rain within 7 DAA, respectively. Although the low rain at all three sites was probably inadequate to sufficiently activate the soil-applied grass herbicides; the grass herbicides would have provided minimal control of ragweed. In contrast, isoxaflutole + metribuzin was activated sufficiently and controlled common ragweed $82 \%$ to $100 \% 12$ WAA. By 14 DAA, sites 1, 3 and 5 received 7.3, 7.2 and $12.5 \mathrm{~mm}$ of rainfall. At $4 \mathrm{WAA}$ the grass herbicides provided $0 \%$ to $14 \%$ common ragweed control which is similar to a study by Soltani et al. [16], who found dimethenamid-P, pethoxamid, pyroxasulfone and S-metolachlor controlled common ragweed $8 \%$ to $27 \%$ and did not reduce biomass. The same study reported that isoxaflutole $\left(105 \mathrm{~g}\right.$ a.i $\left.\cdot \mathrm{ha}^{-1}\right)+$ atrazine $\left(1063 \mathrm{~g} \mathrm{a} \cdot \mathrm{i} \cdot \mathrm{ha}^{-1}\right)$ controlled common ragweed $97 \%$ to $98 \%$ which is consistent with isoxaflutole + metribuzin in this study. Generally, the addition of a grass herbicide to isoxaflutole + metribuzin did not enhance common ragweed control compared to isoxaflutole + metribuzin applied alone. 


\subsection{Velvetleaf}

Velvetleaf (Abutilon theophrasti Medik.) was assessed at 3 sites in this study (Table 6). There was a significant site by treatment interaction (data not shown); sites were separated into two groups, site 1 and 2 were combined and site 3 was analyzed separately.

At $12 \mathrm{WAA}$, at sites 1 and 2, pendimethalin, dimethenamid-P, pethoxamid, pyroxasulfone and S-metolachlor controlled velvetleaf 58, 46, 43, 52 and 33\%; they did not differ statistically (Table 6). Isoxaflutole + metribuzin at the low, medium and high rates controlled velvetleaf $91 \%$ to $100 \%$. The high rate provided higher velvetleaf control than the grass herbicides, the medium rate controlled velvetleaf more than dimethenamid-P, pethoxamid and S-metolachlor and the low rate controlled velvetleaf better than S-metolachlor. Pendimethalin, dimethenamid-P, pethoxamid, pyroxasulfone or S-metolachlor plus isoxaflutole + metribuzin controlled velvetleaf 99\%, 99\%, 89\%, 99\% and 93\%, respectively. Each tank-mix improved velvetleaf control compared to the grass herbicide alone with the exception of pethoxamid. There was no increase in velvetleaf control with the addition of a grass herbicide to isoxaflutole + metribuzin compared to isoxaflutole + metribuzin alone. At site 3 , all grass herbicides provided similar velvetleaf control ranging from $33 \%$ to $72 \%$. Isoxaflutole + metribuzin at the low, medium and high rate controlled velvetleaf $99 \%$ to $100 \%$, providing higher control than pethoxamid and S-metolachlor. The grass herbicides plus isoxaflutole + metribuzin controlled velvetleaf $98 \%$ to $100 \%$. There was no improvement in velvetleaf control when isoxaflutole + metribuzin was added to pendimethalin, dimethenamid-P and pyroxasulfone. The addition of a grass herbicide to isoxaflutole + metribuzin did not improve velvetleaf control.

At $8 \mathrm{WAA}$, at sites 1 and 2, no treatment reduced velvetleaf density compared to the untreated control (Table 6). Pendimethalin, dimethenamid-P or S-metolachlor plus isoxaflutole + metribuzin reduced density $96 \%$, $93 \%$ and $90 \%$, respectively, compared to the respective grass herbicide applied alone. Isoxaflutole + metribuzin at the high rate reduced velvetleaf density more than the grass herbicides applied alone. The medium rate reduced velvetleaf density more than pendimethalin, dimethenamid-P and S-metolachlor applied alone and the low rate did not differ from any herbicide treatment. At site 3, no herbicide treatment reduced density compared to the untreated control and there were no treatment differences.

At $8 \mathrm{WAA}$, at sites 1 and 2, there was no reduction in velvetleaf biomass with any of the herbicides treatments compared to the untreated control (Table 6). At site 3, no herbicide treatment reduced velvetleaf biomass compared to the untreated control; however, isoxaflutole + metribuzin at the low and medium rate and pendimethalin, dimethenamid-P or S-metolachlor plus isoxaflutole + metribuzin reduced velvetleaf biomass compared to pethoxamid applied alone.

In summary, generally, the grass herbicides evaluated provided poor control of velvetleaf. At site 3, dimethenamid-P and pyroxasulfone provided suppression 
Table 6. Velvetleaf control at 12 WAA and density and biomass at 8 WAA from 7 field experiments conducted in Ontario, Canada in 2017 and $2018^{\mathrm{a}}$.

\begin{tabular}{|c|c|c|c|c|c|c|c|}
\hline \multirow{3}{*}{ Treatment } & \multirow{3}{*}{ Rate } & \multicolumn{2}{|c|}{ Control 12 WAA } & \multicolumn{2}{|c|}{ Density } & \multicolumn{2}{|c|}{ Biomass } \\
\hline & & Sites & Sites & Sites & Sites & Sites & Sites \\
\hline & & 1,2 & 3 & 1,2 & 3 & 1,2 & 3 \\
\hline & $\mathrm{g} a \cdot \mathrm{i} \cdot \mathrm{ha}^{-1}$ & \multicolumn{2}{|c|}{$\%$} & \multicolumn{2}{|c|}{$\# \mathrm{~m}^{-2}$} & \multicolumn{2}{|c|}{$\mathrm{g} \cdot \mathrm{m}^{-2}$} \\
\hline Untreated Control & & & & $2.7 \mathrm{abcd}$ & $4.6 \mathrm{a}$ & $1.6 \mathrm{a}$ & $8.0 \mathrm{ab}$ \\
\hline Dimethenamid-P & 544 & $46 \mathrm{~cd}$ & $61 \mathrm{ab}$ & $4.3 \mathrm{~cd}$ & $3.7 \mathrm{a}$ & $2.0 \mathrm{a}$ & $4.6 \mathrm{ab}$ \\
\hline Pethoxamid & 840 & $43 \mathrm{~cd}$ & $36 b$ & $4.0 \mathrm{bcd}$ & $3.9 \mathrm{a}$ & $1.8 \mathrm{a}$ & $12.0 \mathrm{~b}$ \\
\hline Pyroxasulfone & 125 & $52 \mathrm{bcd}$ & $72 \mathrm{ab}$ & $4.6 \mathrm{bcd}$ & $0.9 \mathrm{a}$ & $5.4 \mathrm{a}$ & $0.7 \mathrm{ab}$ \\
\hline S-metolachlor & 1050 & $33 d$ & $33 b$ & $3.2 \mathrm{~cd}$ & $2.0 \mathrm{a}$ & $1.9 \mathrm{a}$ & $10.9 \mathrm{ab}$ \\
\hline Isoxaflutole + Metribuzin & $79+315$ & $96 a b$ & $99 a$ & $0.2 \mathrm{ab}$ & $0.1 \mathrm{a}$ & $0.4 \mathrm{a}$ & $0.1 \mathrm{a}$ \\
\hline Isoxaflutole + Metribuzin & $105+420$ & $100 \mathrm{a}$ & $100 \mathrm{a}$ & $0.2 \mathrm{a}$ & $2.2 \mathrm{a}$ & $0.4 \mathrm{a}$ & $2.1 \mathrm{ab}$ \\
\hline Pendimethalin + Isoxaflutole + Metribuzin & $1000+52.5+210$ & $99 a$ & $98 \mathrm{a}$ & $0.2 \mathrm{a}$ & $0.1 \mathrm{a}$ & $0.1 \mathrm{a}$ & $0.1 \mathrm{a}$ \\
\hline Dimethenamid-P + Isoxaflutole + Metribuzin & $544+52.5+210$ & $99 a$ & $100 \mathrm{a}$ & $0.3 \mathrm{a}$ & $0.1 \mathrm{a}$ & $0.3 \mathrm{a}$ & $0.1 \mathrm{a}$ \\
\hline Pethoxamid + Isoxaflutole + Metribuzin & $840+52.5+210$ & $89 \mathrm{abc}$ & $99 a$ & $1.0 \mathrm{abcd}$ & $0.3 \mathrm{a}$ & $1.6 \mathrm{a}$ & $0.5 \mathrm{ab}$ \\
\hline Pyroxasulfone + Isoxaflutole + Metribuzin & $125+52.5+210$ & $99 \mathrm{a}$ & $98 \mathrm{a}$ & $0.5 \mathrm{abc}$ & $0.3 \mathrm{a}$ & $1.2 \mathrm{a}$ & $0.8 \mathrm{ab}$ \\
\hline S-metolachlor + Isoxaflutole + Metribuzin & $1050+52.5+210$ & $93 \mathrm{abc}$ & $99 \mathrm{a}$ & $0.3 \mathrm{ab}$ & $0.1 \mathrm{a}$ & $0.4 \mathrm{a}$ & $0.1 \mathrm{a}$ \\
\hline
\end{tabular}

${ }^{a}$ Means followed by the same letter within a column are not statistically different according to the Tukey-Kramer multiple range test at $p<0.05$.

of velvetleaf. Among the grass herbicides, pyroxasulfone provided the greatest control of velvetleaf, however, at 12 WAA, control only reached $72 \%$. In contrast, other studies have reported that pyroxasulfone $\left(125 \mathrm{~g} \mathrm{a} \cdot \mathrm{i} \cdot \mathrm{ha}^{-1}\right)$ controlled velvetleaf 90\% [15] [17]; however, other studies required rates as high as 166 [18] and $382 \mathrm{~g} \mathrm{a} \cdot \mathrm{i} \cdot \mathrm{ha}^{-1}$ for the same level of control [19]. At sites 1 and 2, the addition of a grass herbicide to isoxaflutole + metribuzin increased velvetleaf control compared to isoxaflutole + metribuzin at the low rate. At site 3 , there was no improvement in velvetleaf control when a grass herbicide was co-applied with isoxaflutole + metribuzin.

\subsection{Foxtail Spp.}

Green foxtail and giant foxtail were combined during evaluations in this study (Table 7). Foxtail spp. populations were present at seven sites and the site by treatment interaction was significant therefore sites were divided into two groups (data not shown); sites 1, 2 and 4 were combined and sites 3, 5, 7 and 9 were combined.

At $12 \mathrm{WAA}$, at sites 1, 2 and 4, pendimethalin, dimethenamid-P, pethoxamid, pyroxasulfone and S-metolachlor controlled foxtail spp. $24 \%$ to $38 \%$, there was no difference in foxtail spp. control among the five soil-applied grass herbicides (Table 7). Isoxaflutole + metribuzin at the low, medium and high rate controlled 
Table 7. Green and giant foxtail control at 12 WAA and density and biomass at 8 WAA from 7 field experiments conducted in Ontario, Canada in 2017 and $2018^{\mathrm{a}}$.

\begin{tabular}{|c|c|c|c|c|c|c|c|}
\hline \multirow{3}{*}{ Treatment } & \multirow{3}{*}{ Rate } & \multicolumn{2}{|c|}{ Control 12 WAA } & \multicolumn{2}{|c|}{ Density } & \multicolumn{2}{|c|}{ Biomass } \\
\hline & & Sites & Sites & Sites & Sites & Sites & Sites \\
\hline & & $1,2,4$ & $3,5,7,9$ & $1,2,4$ & $3,5,7,9$ & $1,2,4$ & $3,5,7,9$ \\
\hline & $\mathrm{g} \mathrm{a} \cdot \mathrm{i} \cdot \mathrm{ha}^{-1}$ & \multicolumn{2}{|c|}{$\%$} & \multicolumn{2}{|c|}{$\# \mathrm{~m}^{-2}$} & \multicolumn{2}{|c|}{$\mathrm{g} \cdot \mathrm{m}^{-2}$} \\
\hline Untreated Control & & & & $64.5 \mathrm{a}$ & & $59.2 b$ & $44.4 \mathrm{~b}$ \\
\hline Dimethenamid-P & 544 & $26 \mathrm{e}$ & $84 \mathrm{abc}$ & $25.1 \mathrm{a}$ & $7.5 \mathrm{a}$ & $35.9 \mathrm{ab}$ & $6.6 a$ \\
\hline Pethoxamid & 840 & $24 \mathrm{e}$ & $59 c$ & $26.8 \mathrm{a}$ & $18.2 \mathrm{ab}$ & $35.1 \mathrm{ab}$ & $11.6 \mathrm{ab}$ \\
\hline Pyroxasulfone & 125 & $38 \mathrm{bcde}$ & $83 \mathrm{abc}$ & $29.8 \mathrm{a}$ & $19.2 \mathrm{ab}$ & $29.0 \mathrm{ab}$ & $8.8 \mathrm{ab}$ \\
\hline S-metolachlor & 1050 & 31de & $86 a b c$ & $32.7 \mathrm{a}$ & $6.8 \mathrm{a}$ & $38.8 \mathrm{ab}$ & $3.0 \mathrm{a}$ \\
\hline Isoxaflutole + Metribuzin & $79+315$ & $58 \mathrm{abcde}$ & $90 \mathrm{abc}$ & $21.9 \mathrm{a}$ & $8.5 \mathrm{a}$ & $20.2 \mathrm{ab}$ & $6.3 \mathrm{a}$ \\
\hline Isoxaflutole + Metribuzin & $105+420$ & $78 \mathrm{a}$ & $96 a$ & $17.4 \mathrm{a}$ & $6.8 \mathrm{a}$ & $14.8 \mathrm{ab}$ & $3.3 \mathrm{a}$ \\
\hline Pendimethalin + Isoxaflutole + Metribuzin & $1000+52.5+210$ & $81 \mathrm{abc}$ & $87 \mathrm{abc}$ & $16.1 \mathrm{a}$ & $5.2 \mathrm{a}$ & $10.2 \mathrm{a}$ & $3.3 \mathrm{a}$ \\
\hline Dimethenamid-P + Isoxaflutole + Metribuzin & $544+52.5+210$ & $84 \mathrm{ab}$ & $96 \mathrm{ab}$ & $19.8 \mathrm{a}$ & $2.7 \mathrm{a}$ & $16.5 \mathrm{ab}$ & $1.67 \mathrm{a}$ \\
\hline Pethoxamid + Isoxaflutole + Metribuzin & $840+52.5+210$ & $53 \mathrm{abcde}$ & $88 \mathrm{abc}$ & $29.3 \mathrm{a}$ & $7.9 \mathrm{a}$ & $30.3 \mathrm{ab}$ & $5.0 \mathrm{a}$ \\
\hline Pyroxasulfone + Isoxaflutole + Metribuzin & $125+52.5+210$ & $65 \mathrm{abcd}$ & $93 \mathrm{ab}$ & $18.8 \mathrm{a}$ & $8.1 \mathrm{a}$ & $17.0 \mathrm{ab}$ & $4.4 \mathrm{a}$ \\
\hline S-metolachlor + Isoxaflutole + Metribuzin & $1050+52.5+210$ & 59abcde & $96 a$ & $18.3 \mathrm{a}$ & $2.7 \mathrm{a}$ & $19.2 \mathrm{ab}$ & $2.3 \mathrm{a}$ \\
\hline
\end{tabular}

${ }^{a}$ Means followed by the same letter within a column are not statistically different according to the Tukey-Kramer multiple range test at $p<0.05$.

foxtail spp. 50\%, 58\% and 78\%, respectively. Control among the rates of isoxaflutole + metribuzin did not differ, additionally the low and medium rate did not differ compared to the grass herbicides; however, the high rate provided $40 \%$ to $54 \%$ greater foxtail spp. control compared to the grass herbicides. The tank-mixtures of a grass herbicides plus isoxaflutole + metribuzin controlled foxtail spp. $53 \%$ to $84 \%$, there was no difference in control with these five herbicide treatments. Dimethenamid-P was the only grass herbicide which benefited from the addition of isoxaflutole + metribuzin where control increased $58 \%$. The grass herbicides plus isoxaflutole + metribuzin did not differ from the varying rates of isoxaflutole + metribuzin. At sites 3, 5, 7 and 9, pendimethalin, dimethenamid-P, pethoxamid, pyroxasulfone and S-metolachlor controlled foxtail spp. $59 \%$ to $86 \%$; there were no differences in foxtail spp.control with the grass herbicides. Isoxaflutole + metribuzin at the low, medium and high rate controlled foxtail spp. $84 \%, 90 \%$ and $96 \%$, respectively; there was no difference in control among the three rates evaluated. The low and medium rate did not differ from the grass herbicides. The high rate provided $26 \%$ and $37 \%$ greater control than pendimethalin and pethoxamid, respectively, but did not differ from dimethenamid-P, pyroxasulfone and S-metolachlor. The grass herbicides plus isoxaflutole + metribuzin controlled foxtail spp. $87 \%$ to $96 \%$ and did not differ among each other or with isoxaflutole + metribuzin at the low, medium or high rate. 
There was no difference in foxtail spp. control with the grass herbicides applied alone or in a tank-mixture with isoxaflutole + metribuzin. S-metolachlor + isoxaflutole + metribuzin controlled foxtail spp. $26 \%$ and $37 \%$ more than pendimethalin and pethoxamid, respectively. Additionally, dimethenamid-P or pyroxa-s ulfone plus isoxaflutole + metribuzin controlled foxtail spp. $34 \%$ to $37 \%$ more than pethoxamid.

At $8 \mathrm{WAA}$, at sites 1, 2 and 4, there was no decrease in foxtail spp. density with the herbicide treatments evaluated (Table 7). At sites 3, 5, 7 and 9 all herbicide treatments reduced foxtail spp. density $85 \%$ to $97 \%$ except for pethoxamid and pyroxasulfone. There was no difference in foxtail spp. density among the herbicide treatments evaluated.

At 8 WAA, at sites 1, 2 and 4, pendimethalin + isoxaflutole + metribuzin was the only treatment that reduced foxtail spp. biomass compared to the untreated control, it reduced biomass $83 \%$ (Table 7). There were no other treatment differences. At sites 3, 5, 7 and 9, all treatments reduced biomass $85 \%$ to $96 \%$ compared to the untreated control except for pethoxamid and pyroxasulfone. No herbicide treatments differed among each other.

In summary, at sites 1, 2 and 4, there was lower weed control than at sites 3, 5, 7 and 9. Generally, more rainfall was received at sites 3, 5, 7 and 9, by 28 DAA, compared to sites 1,2 and 4 which may partially explain the reduced foxtail spp. control at sites 1, 2 and 4; however, site 3 received a lower amount of rain during this time period than site 2 . Generally, at sites 1, 2 and 4, pyroxasulfone was the grass herbicide that provided the best control of foxtail spp.; in contrast, at sites 3, 5, 7 and 9, S-metolachlor provided the best control. At both site groups the grass herbicides plus isoxaflutole + metribuzin provided higher foxtail spp. control than isoxaflutole + metribuzin at the low rate.

\subsection{Yellow Foxtail}

Yellow foxtail (Setaria pumila Poir. Roem. \& Schult.) was evaluated at sites 7 and 9 in this study (Table 8). The site by treatment interaction was not significant. Therefore, the sites were pooled for analysis (data not shown).

At 12 WAA, the grass herbicides controlled yellow foxtail $55 \%$ to $90 \%$, there was no difference in control among the five herbicides (Table 8). Isoxaflutole + metribuzin at the low, medium and high rate controlled yellow foxtail $81 \%$ to $92 \%$ which was similar to pendimethalin, dimethenamid-P, pethoxamid, pyroxasulfone and S-metolachlor. The tank-mixtures of a grass herbicide plus isoxaflutole + metribuzin controlled yellow foxtail $87 \%$ to $97 \%$. The addition of isoxaflutole + metribuzin to a grass herbicide did not increase control compared to the respective grass herbicide applied alone; however, pendimethalin, dimethenamid-P or S-metolachlor plus isoxaflutole + metribuzin provided greater yellow foxtail control than pethoxamid. At $8 \mathrm{WAA}$, the herbicide treatments evaluated did not reduce yellow foxtail density or biomass compared to the untreated control (Table 8). 
Table 8. Yellow foxtail control at 12 WAA and density and biomass at 8 WAA from 7 field experiments conducted in Ontario, Canada in 2017 and $2018^{\mathrm{a}}$.

\begin{tabular}{ccccc}
\hline & & Control 12 & Density & Biomass \\
\hline Treatment & RAte & Sites & Sites & Sites \\
& $\mathrm{g} \mathrm{a} \cdot \mathrm{i} \cdot \mathrm{ha}^{-1}$ & $\%$ & $\# \mathrm{~m}^{-2}$ & $\mathrm{~g} \cdot \mathrm{m}^{-2}$ \\
\hline Untreated Control & & & $11.4 \mathrm{a}$ & $10.1 \mathrm{a}$ \\
Pendimethalin & 1000 & $79 \mathrm{ab}$ & $3.8 \mathrm{a}$ & $3.1 \mathrm{a}$ \\
Dimethenamid-P & 544 & $75 \mathrm{ab}$ & $3.2 \mathrm{a}$ & $2.3 \mathrm{a}$ \\
Pethoxamid & 840 & $55 \mathrm{~b}$ & $3.5 \mathrm{a}$ & $2.2 \mathrm{a}$ \\
Pyroxasulfone & 125 & $80 \mathrm{ab}$ & $6.7 \mathrm{a}$ & $6.3 \mathrm{a}$ \\
S-metolachlor & 1050 & $90 \mathrm{ab}$ & $2.2 \mathrm{a}$ & $1.7 \mathrm{a}$ \\
Isoxaflutole + Metribuzin & $52.5+210$ & $81 \mathrm{ab}$ & $2.9 \mathrm{a}$ & $2.9 \mathrm{a}$ \\
Isoxaflutole + Metribuzin & $79+315$ & $90 \mathrm{ab}$ & $4.3 \mathrm{a}$ & $2.8 \mathrm{a}$ \\
Isoxaflutole + Metribuzin & $105+420$ & $92 \mathrm{ab}$ & $2.2 \mathrm{a}$ & $1.5 \mathrm{a}$ \\
Pendimethalin + Isoxaflutole + Metribuzin & $1000+52.5+210$ & $94 \mathrm{a}$ & $2.5 \mathrm{a}$ & $2.6 \mathrm{a}$ \\
Dimethenamid-P + Isoxaflutole + Metribuzin & $544+52.5+210$ & $94 \mathrm{a}$ & $1.2 \mathrm{a}$ & $0.6 \mathrm{a}$ \\
Pethoxamid + Isoxaflutole + Metribuzin & $840+52.5+210$ & $87 \mathrm{ab}$ & $3.8 \mathrm{a}$ & $2.8 \mathrm{a}$ \\
Pyroxasulfone + Isoxaflutole + Metribuzin & $125+52.5+210$ & $90 \mathrm{ab}$ & $4.5 \mathrm{a}$ & $2.3 \mathrm{a}$ \\
S-metolachlor + Isoxaflutole + Metribuzin & $1050+52.5+210$ & $97 \mathrm{a}$ & $0.8 \mathrm{a}$ & $0.8 \mathrm{a}$ \\
\hline
\end{tabular}

${ }^{a}$ Means followed by the same letter within a column are not statistically different according to the Tukey-Kramer multiple range test at $p<0.05$.

In summary, the addition of a grass herbicide to isoxaflutole + metribuzin numerically increased yellow foxtail control, although differences were not statistically significant. S-metolachlor with and without isoxaflutole + metribuzin had the highest level of control at 12 WAA and the largest reduction in density and biomass compared to the other grass herbicides.

\subsection{Barnyardgrass}

Barnyardgrass control was assessed at five sites in this study (Table 9). There was a significant site by treatment interaction, therefore, sites 1 and 2 were combined and sites 5, 6 and 9 were combined for analysis (data not shown).

At $12 \mathrm{WAA}$, at sites 1 and 2, there were no treatment differences, all herbicides controlled barnyardgrass 32 to $81 \%$ (Table 9). At sites 5, 6 and 9, pendimethalin, dimethenamid-P, pethoxamid, pyroxasulfone and S-metolachlor controlled barnyardgrass 48 , 96, 72, 95 and 98\%, respectively. Dimethenamid-P, pyroxasulfone and S-metolachlor provided better control than pendimethalin. Isoxaflutole + metribuzin at the low, medium and high rates controlled barnyardgrass $92 \%$ to $97 \%$ and did not differ, they generally higher barnyardgrass control than pendimethalin. The tank-mixtures of a grass herbicide plus isoxaflutole + metribuzin controlled barnyardgrass $91 \%$ to $100 \%$ and did not differ. 
Table 9. Barnyardgrass control at 12 WAA and density and biomass at 8 WAA from 7 field experiments conducted in Ontario, Canada in 2017 and $2018^{\mathrm{a}}$.

\begin{tabular}{|c|c|c|c|c|c|c|c|}
\hline \multirow{3}{*}{ Treatment } & \multirow{3}{*}{ Rate } & \multicolumn{2}{|c|}{ Control 12 WAA } & \multicolumn{2}{|c|}{ Density } & \multicolumn{2}{|c|}{ Biomass } \\
\hline & & Sites & Sites & Sites & Sites & Sites & Sites \\
\hline & & 1,2 & $5,6,9$ & 1,2 & $5,6,9$ & 1,2 & $5,6,9$ \\
\hline & \multirow[t]{2}{*}{$\mathrm{g} \mathrm{a} \cdot \mathrm{i} \cdot \mathrm{ha}^{-1}$} & \multicolumn{2}{|c|}{$\%$} & \multicolumn{2}{|c|}{$\# \mathrm{~m}^{-2}$} & \multicolumn{2}{|c|}{$\mathrm{g} \cdot \mathrm{m}^{-2}$} \\
\hline Untreated Control & & & & $13.1 \mathrm{a}$ & $5.8 \mathrm{~b}$ & $11.6 \mathrm{a}$ & $5.3 \mathrm{ab}$ \\
\hline Dimethenamid-P & 544 & $45 a$ & $96 a b$ & $7.8 \mathrm{a}$ & $0.9 \mathrm{ab}$ & $7.0 \mathrm{a}$ & $0.3 \mathrm{a}$ \\
\hline Pethoxamid & 840 & $56 a$ & $72 \mathrm{bc}$ & $7.7 \mathrm{a}$ & $2.6 \mathrm{ab}$ & $5.3 \mathrm{a}$ & $3.3 \mathrm{ab}$ \\
\hline Pyroxasulfone & 125 & $47 a$ & $95 \mathrm{ab}$ & $7.4 \mathrm{a}$ & $1.4 \mathrm{ab}$ & $4.9 \mathrm{a}$ & $1.4 \mathrm{ab}$ \\
\hline S-metolachlor & 1050 & $32 \mathrm{a}$ & $98 \mathrm{ab}$ & $6.3 \mathrm{a}$ & $0.7 \mathrm{ab}$ & $7.8 \mathrm{a}$ & $0.7 \mathrm{ab}$ \\
\hline Isoxaflutole + Metribuzin & $79+315$ & $59 a$ & $95 \mathrm{ab}$ & $9.1 \mathrm{a}$ & $1.0 \mathrm{ab}$ & $9.3 \mathrm{a}$ & $1.9 \mathrm{ab}$ \\
\hline Isoxaflutole + Metribuzin & $105+420$ & $69 a$ & $97 \mathrm{ab}$ & $10.1 \mathrm{a}$ & $0.6 \mathrm{a}$ & $12.2 \mathrm{a}$ & $0.3 \mathrm{a}$ \\
\hline Pendimethalin + Isoxaflutole + Metribuzin & $1000+52.5+210$ & $68 \mathrm{a}$ & $91 \mathrm{ab}$ & $5.6 \mathrm{a}$ & $0.7 \mathrm{ab}$ & $3.7 \mathrm{a}$ & $1.6 \mathrm{ab}$ \\
\hline Dimethenamid-P + Isoxaflutole + Metribuzin & $544+52.5+210$ & $81 \mathrm{a}$ & $100 \mathrm{a}$ & $4.2 \mathrm{a}$ & $0.4 \mathrm{a}$ & $1.5 \mathrm{a}$ & $0.2 \mathrm{a}$ \\
\hline Pethoxamid + Isoxaflutole + Metribuzin & $840+52.5+210$ & $70 \mathrm{a}$ & $93 \mathrm{ab}$ & $5.6 \mathrm{a}$ & $0.6 \mathrm{ab}$ & $3.7 \mathrm{a}$ & $0.9 \mathrm{ab}$ \\
\hline Pyroxasulfone + Isoxaflutole + Metribuzin & $125+52.5+210$ & $73 a$ & $99 \mathrm{ab}$ & $4.6 \mathrm{a}$ & $0.5 \mathrm{a}$ & $3.0 \mathrm{a}$ & $0.5 \mathrm{a}$ \\
\hline S-metolachlor +Isoxaflutole + Metribuzin & $1050+52.5+210$ & $77 \mathrm{a}$ & $99 \mathrm{ab}$ & $8.5 \mathrm{a}$ & $0.3 \mathrm{a}$ & $4.3 \mathrm{a}$ & $0.4 \mathrm{a}$ \\
\hline
\end{tabular}

${ }^{a}$ Means followed by the same letter within a column are not statistically different according to the Tukey-Kramer multiple range test at $p<0.05$.

Dimethenamid-P + isoxaflutole + metribuzin provided $52 \%$ and $28 \%$ better control than pendimethalin and pethoxamid, respectively.

At $8 \mathrm{WAA}$, at sites 1 and 2, there was no decrease in barnyardgrass density with the herbicide treatments evaluated compared to the untreated control (Table 9). At sites 5, 6 and 9, isoxaflutole + metribuzin at the high rate, and dimethenamid-P, pyroxasulfone or S-metolachlor plus isoxaflutole + metribuzin reduced barnyardgrass density $90 \%$ to $94 \%$ compared to the untreated control. The other herbicide treatments evaluated did not reduce barnyardgrass density relative to the untreated control.

At 8 WWA, at sites 1 and 2, the herbicide treatments evaluated did not reduce barnyardgrass biomass compared to the untreated control (Table 9). At sites 5, 6 and 9, no treatments reduced biomass compared to the untreated control but there were treatment differences. Dimethenamid-P, isoxaflutole + metribuzin at the high rate and dimethenamid-P, pyroxasulfone or S-metolachlor plus isoxaflutole + metribuzin reduced biomass $93 \%$ to $97 \%$ compared to pendimethalin.

In summary, barnyardgrass control was influenced by amount of rainfall 0 to $7 \mathrm{DAA}$ and 0 to $14 \mathrm{DAA}$. Sites 1 and 2 received 5 and $2.7 \mathrm{~mm}$ of rain 0 to 7 DAA, respectively and had poorer weed control than sites 5, 6 and 9 which received $0.8,9.8$ and $10.8 \mathrm{~mm}$ of rain, respectively. Although site 5, had less rainfall than sites 1 and 2, it received more rain by 14 DAA, which allowed for acti- 
vation of the herbicides. At sites 5, 6 and 9, S-metolachlor provided 50\% higher control than pendimethalin 12 WAA. However, opposite results were found by Janak and Grichar [20] where pendimethalin provided 29\% greater control than S-metolachlor and dimethenamid-P provided 31\% greater barnyardgrass control than pyroxasulfone.

\subsection{Witchgrass}

Witchgrass populations occurred at sites 6 and 7 in this study (Table 10). There was no significant site by treatment interaction thus sites were pooled for analysis (data not shown). At12WAA, the herbicide treatments evaluated controlled witchgrass 83 to $98 \%$ (Table 10). There was no difference in witchgrass control among the herbicide treatments evaluated.

At 8 WAA, dimethenamid-P, pyroxasulfone, S-metolachlor, isoxaflutole + metribuzin at the three rates and the grass herbicides plus isoxaflutole + metribuzin reduced witchgrass density $96 \%$ to $99 \%$ compared to the untreated control (Table 10). Pendimethalin and pethoxamid did not reduce witchgrass density compared to the untreated control, although they did reduce witchgrass density similar to the other herbicide treatments evaluated.

At 8 WAA, all treatments reduced witchgrass biomass $98 \%$ to $99 \%$ compared to the untreated control with the exception of pendimethalin and pethoxamid which did not differ from the untreated control or other herbicide treatments (Table 10).

In summary, the addition of a grass herbicide to isoxaflutole + metribuzin did not improve witchgrass control compared to isoxaflutole + metribuzin at the low, medium or high rate, this may have been due to the high level of control provided by isoxaflutole + metribuzin.

\subsection{Soybean Yield}

Soybean yield had a significant site by treatment interaction (data not shown), therefore sites 1, 2, 3, 4, 5 and 8 were combined, site 6 and 7 were combined and site 9 was analyzed independently (Table 11). At sites 6 and 7, there were no yield differences, all treatments yielded 4.3 to $5.8 \mathrm{~T} \cdot \mathrm{ha}^{-1}$. At sites 1, 2, 3, 4, 5 and 8 , weed interference reduced soybean yield $34 \%$. The only herbicide treatments that resulted in soybean yield similar to the weed-free control were isoxaflutole + metribuzin at the high rate and pyroxasulfone + isoxaflutole + metribuzin. Isoxaflutole at all three rates, in addition to all the grass herbicides plusisoxaflutole + metribuzin yielded 0.7 to $1.0 \mathrm{~T} \cdot \mathrm{ha}^{-1}$ higher than the untreated control. Soybean yield with the grass herbicides alone did not differ from the untreated control. Soybean yield at site 9 in the weed-free control was lower than at the other site groups. Weed interference reduced soybean yield $76 \%$ at this site. Equivalent yields to the weed-free control of 2.6 to $3.8 \mathrm{~T} \cdot \mathrm{ha}^{-1}$ were obtained with the application of isoxaflutole + metribuzin at the medium and high rate, as well as the grass herbicides plus isoxaflutole + metribuzin. Soybean yield with dimethenamid-P, pethoxamid, pyroxasulfone and S-metolachlor did not differ 
Table 10. Witchgrass control at 12 WAA and density and biomass at 8 WAA from 7 field experiments conducted in Ontario, Canada in 2017 and $2018^{\mathrm{a}}$.

\begin{tabular}{|c|c|c|c|c|}
\hline & & $\begin{array}{c}\text { Control } 12 \\
\text { WAA }\end{array}$ & Density & Biomass \\
\hline \multirow{2}{*}{ Treatment } & \multirow{2}{*}{ Rate } & Site & Site & Site \\
\hline & & 6,7 & 6,7 & 6,7 \\
\hline & $\mathrm{g} a \cdot \mathrm{i} \cdot \mathrm{ha}^{-1}$ & $\%$ & $\# \mathrm{~m}^{-2}$ & $\mathrm{~g} \cdot \mathrm{m}^{-2}$ \\
\hline Untreated Control & & & $25.3 b$ & $19.8 \mathrm{~b}$ \\
\hline Pendimethalin & 1000 & $83 a$ & $2.4 \mathrm{ab}$ & $2.7 \mathrm{ab}$ \\
\hline Dimethenamid-P & 544 & $96 a$ & $0.8 \mathrm{a}$ & $0.3 \mathrm{a}$ \\
\hline Pethoxamid & 840 & $83 a$ & $3.9 \mathrm{ab}$ & $2.6 \mathrm{ab}$ \\
\hline Pyroxasulfone & 125 & $98 \mathrm{a}$ & $0.7 \mathrm{a}$ & $0.3 \mathrm{a}$ \\
\hline S-metolachlor & 1050 & $91 \mathrm{a}$ & $1.0 \mathrm{a}$ & $0.3 \mathrm{a}$ \\
\hline Isoxaflutole + Metribuzin & $52.5+210$ & $94 \mathrm{a}$ & $0.8 \mathrm{a}$ & $0.4 \mathrm{a}$ \\
\hline Isoxaflutole + Metribuzin & $79+315$ & $99 \mathrm{a}$ & $0.6 \mathrm{a}$ & $0.2 \mathrm{a}$ \\
\hline Isoxaflutole + Metribuzin & $105+420$ & $99 \mathrm{a}$ & $0.4 \mathrm{a}$ & $0.2 \mathrm{a}$ \\
\hline Pendimethalin + Isoxaflutole + Metribuzin & $1000+52.5+210$ & $100 \mathrm{a}$ & $0.2 \mathrm{a}$ & $0.1 \mathrm{a}$ \\
\hline Dimethenamid-P + Isoxaflutole + Metribuzin & $544+52.5+210$ & $99 \mathrm{a}$ & $0.2 \mathrm{a}$ & $0.1 \mathrm{a}$ \\
\hline Pethoxamid + Isoxaflutole + Metribuzin & $840+52.5+210$ & $98 \mathrm{a}$ & $0.4 \mathrm{a}$ & $0.1 \mathrm{a}$ \\
\hline Pyroxasulfone + Isoxaflutole + Metribuzin & $125+52.5+210$ & $99 \mathrm{a}$ & $0.2 \mathrm{a}$ & $0.1 \mathrm{a}$ \\
\hline S-metolachlor + Isoxaflutole + Metribuzin & $1050+52.5+210$ & $100 \mathrm{a}$ & $0.1 \mathrm{a}$ & $0.1 \mathrm{a}$ \\
\hline
\end{tabular}

${ }^{a}$ Means followed by the same letter within a column are not statistically different according to the Tukey-Kramer multiple range test at $p<0.05$.

Table 11. Soybean yield from 9 field experiments in Ontario, Canada in 2017 and $2018^{\mathrm{a}}$.

\begin{tabular}{|c|c|c|c|c|}
\hline \multirow[b]{2}{*}{ Treatment } & \multirow[b]{2}{*}{ Rate } & \multicolumn{3}{|c|}{ Soybean seed yield } \\
\hline & & $\begin{array}{l}\text { Sites } \\
6,7\end{array}$ & $\begin{array}{c}\text { Sites } 1,2,3 \\
4,5,8\end{array}$ & $\begin{array}{c}\text { Sites } \\
9\end{array}$ \\
\hline & $\mathrm{g} a \cdot \mathrm{i} \cdot \mathrm{ha}^{-1}$ & & $\mathrm{~T} \cdot \mathrm{ha}^{-1}$ & \\
\hline Untreated Control & & $4.3 \mathrm{a}$ & $3.1 \mathrm{e}$ & $0.9 \mathrm{~g}$ \\
\hline Weed Free & & $5.8 \mathrm{a}$ & $4.7 \mathrm{a}$ & $3.8 \mathrm{a}$ \\
\hline Pendimethalin & 1000 & $5.0 \mathrm{a}$ & $3.5 \mathrm{bcde}$ & $1.9 \mathrm{bcdef}$ \\
\hline Dimethenamid-P & 544 & $5.2 \mathrm{a}$ & $3.4 \mathrm{cde}$ & $1.5 \mathrm{defg}$ \\
\hline Pethoxamid & 840 & $5.1 \mathrm{a}$ & 3.3ed & $1.5 \mathrm{efg}$ \\
\hline Pyroxasulfone & 125 & $4.9 \mathrm{a}$ & $3.5 \mathrm{bcde}$ & $1.6 \mathrm{cdefg}$ \\
\hline S-metolachlor & 1050 & $4.9 \mathrm{a}$ & $3.3 \mathrm{ed}$ & $1.1 \mathrm{fg}$ \\
\hline Isoxaflutole + Metribuzin & $52.5+210$ & $4.8 \mathrm{a}$ & $3.8 \mathrm{bcd}$ & $0.3 \mathrm{bcde}$ \\
\hline Isoxaflutole + Metribuzin & $79+315$ & $5.2 \mathrm{a}$ & $4.0 \mathrm{~b}$ & $2.6 \mathrm{abcd}$ \\
\hline Isoxaflutole + Metribuzin & $105+420$ & $5.1 \mathrm{a}$ & $4.1 \mathrm{ab}$ & $2.9 \mathrm{ab}$ \\
\hline Pendimethalin + Isoxaflutole + Metribuzin & $1000+52.5+210$ & $4.9 \mathrm{a}$ & $4.0 \mathrm{~b}$ & $3.1 \mathrm{ab}$ \\
\hline Dimethenamid-P + Isoxaflutole + Metribuzin & $544+52.5+210$ & $5.2 \mathrm{a}$ & $4.1 \mathrm{~b}$ & $2.7 \mathrm{abc}$ \\
\hline Pethoxamid + Isoxaflutole + Metribuzin & $840+52.5+210$ & $4.7 \mathrm{a}$ & $3.9 \mathrm{bc}$ & $2.9 \mathrm{ab}$ \\
\hline Pyroxasulfone + Isoxaflutole + Metribuzin & $125+52.5+210$ & $5.3 \mathrm{a}$ & $4.1 \mathrm{ab}$ & $2.9 \mathrm{ab}$ \\
\hline S-metolachlor + Isoxaflutole + Metribuzin & $1050+52.5+210$ & $4.8 \mathrm{a}$ & $4.0 \mathrm{~b}$ & $2.7 \mathrm{abcd}$ \\
\hline
\end{tabular}

${ }^{a}$ Means followed by the same letter within a column are not statistically different according to the Tukey-Kramer multiple range test at $p<0.05$. 
from the untreated control. Reduced weed interference with the application of pendimethalin and isoxaflutole + metribuzin at the low rate resulted in increased soybean yield of 1.0 and 1.4 T.ha ${ }^{-1}$ compared to the untreated control; however, were not equivalent to the weed-free control. The yield potential was lower at site 9 due to low levels of rainfall throughout the growing season.

\section{Conclusion}

General trends suggest the addition of a grass herbicide to isoxaflutole + metribuzin at the low rate increases control of pigweed spp., green and giant foxtail and yellow foxtail regardless of site or assessment timing. Control of other species usually increased with the addition of a grass herbicide to isoxaflutole + metribuzin at the low rate although this was not consistent across all grass herbicides, especially when the low rate of isoxaflutole + metribuzin provided a high level of control. Generally, isoxaflutole + metribuzin at the medium or high rate provided equivalent or better control of most species evaluated than the grass herbicides applied alone or with isoxaflutole + metribuzin at the low rate. The addition of pendimethalin, dimethenamid-P, pethoxamid, pyroxasulfone or S-metolachlor to isoxaflutole + metribuzin may provide an additional effective mode of action which will reduce the selection intensity for the evolution of herbicide-resistant weed biotypes. Weed control varied by species. The grass herbicides, as the name suggests, controlled the grass weed species the best. However, when sites received $>4.9 \mathrm{~mm}$ of rainfall within $7 \mathrm{DAA}$, control of the pigweed spp. and common lambsquarters with pendimethalin, dimethenamid-P and pyroxasulfone was $85 \%$ to $93 \%$ and $62 \%$ to $85 \%$, respectively. The grass herbicides controlled ragweed and velvetleaf $<65 \%$ and $<72 \%$, respectively. Generally, across all sites, pendimethalin and pyroxasulfone provided greater broadleaf weed control than the other grass herbicides. The grass herbicides provided lower control of grass species at sites 1, 2 and 4 than sites 3, 5, 6, 7, 8 and 9. This may be due to lack of activating rainfall; general trends occur where sites 1, 2 and 4 received 2.7 to $5.2 \mathrm{~mm}$ of rain 0 to $7 \mathrm{DAA}$ and sites $3,5,6,7,8$ and 9 received 0.8 to $14.9 \mathrm{~mm}$ of rain 0 to $7 \mathrm{DAA}$. Site 5 received $0.8 \mathrm{~mm}$ of rain 0 to 7 DAA, but there was delayed weed emergence at this location due to the lack of moisture. By 14 DAA, site 5 had received $12.5 \mathrm{~mm}$ of rain which provided moisture to activate the herbicides and control weeds prior to emergence. In general, S-metolachlor provided the most consistent grass control in this study. There was a numeric improvement in the control of all weed species with increasing rates of isoxaflutole + metribuzin in this study. The medium and high rates typically provided higher numeric control of all the species than the grass herbicides applied alone, while the low rate rarely provided similar control to the best grass herbicide for each species.

\section{Limitations}

Due to natural environmental variability, weed species composition, and unforeseen outcomes within these studies, there are limitations on the conclusions 
obtained. Interspecies weed competition may have affected weed control otherwise accounted for by the herbicides in this study due to the variation in weed species and populations at the 10 sites. Some weed species are more competitive in nature, which would potentially suppress other species. Additionally, the competitiveness of differing species at each site may have altered the impact of weed interference on soybean yield. However, in real field situations, it is highly unlikely that two fields will have the exact same weed populations and species, therefore, results in these studies give a general trend to the efficacy of the herbicides.

\section{Fund}

Funding for this project was provided in part by the Ontario Centre of Excellence (OCE) and Bayer CropScience Canada Inc.

\section{Conflicts of Interest}

The authors declare no conflicts of interest regarding the publication of this paper.

\section{References}

[1] Ditschun, S., Soltani, N., Robinson, D.E., Tardiff, F.J., Kaastra, A.C. and Sikkema, P.H. (2016) Control of Glyphosate-Resistant Canada Fleabane (Conyza canadensis (L.) Cronq.) with Isoxaflutole and Metribuzin Tank Mix. Canadian Journal of Plant Science, 96, 72-80. https://doi.org/10.1139/cjps-2015-0121

[2] Anonymous (2017) Converge ${ }^{\oplus}$ Flexx Herbicide Label. Bayer CropScience Canada Inc. Publication, Pest Control Products Act. Reg. No. 22071, Calgary.

[3] Knezevic, S.Z., Sikkema, P.H., Tardif, F., Hammill, A.S., Chandler, K. and Swanton, C.J. (1998) Biologically Effective Dose and Selectivity of RPA 201772 for Presemeergence Weed Control in Corn (Zea mays). Weed Technology, 12, 670-676. https://doi.org/10.1017/S0890037X00044535

[4] Pallett, K.E., Little, J.P., Sheekey, M. andVeerasekaran, P. (1998) The Mode of Action of Isoxaflutole: Physiological Effects, Metabolism and Selectivity. Pesticide Biochemistry and Physiology, 62, 113-124. https://doi.org/10.1006/pest.1998.2378

[5] Trebst, A. (2008) The Mode of Action of Triazine Herbicides in Plants. In: LeBaron, H.M., McFarland, J.E. and Burnside, O.C., Eds., The Triazine Herbicides, Elsevier, Amsterdam, 101-110. https://doi.org/10.1016/B978-044451167-6.50011-8

[6] McWhorter, C.G. and Hartwig, E.E. (1972) Competition of Johnsongrass and Cocklebur with Six Soybean Varieties. Weed Science, 20, 56-59. https://doi.org/10.1017/S0043174500034949

[7] Knake, E.L. and Slife, F.W. (1962) Competition of Seteria faberi with Corn and Soybeans. Weeds, 10, 26-29. https://doi.org/10.2307/4040555

[8] Young, B.G. (2006) Changes in Herbicide Use Patterns and Production Practices Resulting from Glyphosate-Resistant Crops. Weed Technology, 20, 301-307. https://doi.org/10.1614/WT-04-189.1

[9] Anonymous (2017) Unpublished: FMC Agricultural Solutions, Global Technical Solutions, Pethoxamid. Product Bulletin.

[10] Loux, M.M., Doohan, D., Dobbels, A.F., Johnson, W.G., Young, B.G., Legleiter, T.R. 
and Hager, A. (2015) Weed Control Guide: Ohio State University Extension Publication WS16. Ohio State University, Columbus. https://www.extension.purdue.edu/extmedia/WS/WS-16-W.pdf

[11] Yamaji, Y., Honda, H., Hanai, R. and Inoue, J. (2016) Soil and Environmental Factors Affecting the Efficacy of Pyroxasulfone for Weed Control. Journal of Pesticide Science, 41, 1-5. https://doi.org/10.1584/jpestics.D15-047

[12] Tharp, B.E. andKells, J.J. (2002) Residual Herbicides Used in Combination with Glyphosate and Glufosinate in Corn (Zea mays). Weed Technology, 16, 274-281. https://doi.org/10.1614/0890-037X(2002)016[0274:RHUICW]2.0.CO;2

[13] Shapiro, S.S. and Wilk, M.B. (1965) An Analysis of Variance Test for Normality (Complete Samples). Biometrika, 52, 591-611.

https://doi.org/10.1093/biomet/52.3-4.591

[14] Chomas, A.J. and Kells, J.J. (2004) Triazine-Resistant Common Lambsquarters (Chenopodium album) Control in Corn with Preemergence Herbicides. Weed Technology, 18, 551-554. https://doi.org/10.1614/WT-03-077R

[15] Nurse, R.E., Sikkema, P.H. and Robinson, D.E. (2011) Weed Control and Sweet Maize (Zea mays L.) Yield as Affected by Pyroxasulfone Dose. Crop Protection, 30, 789-793. https://doi.org/10.1016/j.cropro.2011.03.026

[16] Soltani, N., Brown, L. and Sikkema, P.H. (2018) Control of Glyphosate-Resistant Common Ragweed in Corn with Pre-Emergence Herbicides. Canadian Journal of Plant Science, 98, 959 962. https://doi.org/10.1139/cjps-2017-0325

[17] Steele, G.L., Porpiglia, P.J. and Chandler, J.M. (2005) Efficacy of KIH-485 on Texas Panicum (Panicum texanum) and Selected Broadleaf Weeds in Corn. Weed Technology, 19, 866-869. https://doi.org/10.1614/WT-04-229R1.1

[18] King, S.R. and Garcia, J.O. (2008) Annual Broadleaf Control with KIH-485 in Glyphosate-Resistant Furrow-Irrigated Corn. Weed Technology, 22, 420-424. https://doi.org/10.1614/WT-07-169.1

[19] Knezevic, S.Z., Datta, A., Scott, J. and Porpiglia, P.J. (2009) Dose-Response Curves of KIH-485 for Preemergence Weed Control in Corn. Weed Technology, 23, 34-39. https://doi.org/10.1614/WT-08-097.1

[20] Janak, T.W. and Grichar, W.J. (2016) Weed Control in Corn (Zea mays L.) as Influenced by Preemergence Herbicides. International Journal of Agronomy, 2016, Article ID: 2607671. https://doi.org/10.1155/2016/2607671 